\title{
Carbonaceous aerosols contributed by traffic and solid fuel burning at a polluted rural site in Northwestern England
}

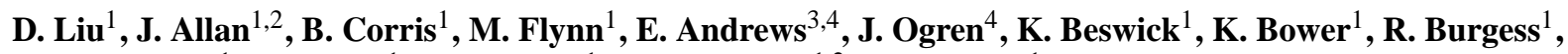 \\ T. Choularton ${ }^{1}$, J. Dorsey ${ }^{1}$, W. Morgan ${ }^{1}$, P. I. Williams ${ }^{1,2}$, and H. Coe ${ }^{1}$ \\ ${ }^{1}$ School of Earth, Atmospheric and Environmental Sciences, The University of Manchester, Oxford Road, \\ Manchester, M13 9PL, UK \\ ${ }^{2}$ National Centre for Atmospheric Science, The University of Manchester, Oxford Road, Manchester, M13 9PL, UK \\ ${ }^{3}$ Cooperative Institute for Research in Environmental Sciences, University of Colorado, Boulder, CO 80309, USA \\ ${ }^{4}$ Earth System Research Laboratory, NOAA, Boulder, CO 80305, USA
}

Received: 15 October 2010 - Published in Atmos. Chem. Phys. Discuss.: 28 October 2010

Revised: 27 January 2011 - Accepted: 9 February 2011 - Published: 18 February 2011

\begin{abstract}
The experiment presented in this paper was conducted at the Holme Moss site, which is located in the southern Pennines region in Northwestern England during November-December 2006. The strong southwesterly wind during the experimental period, which enhanced the transport of urban pollutants from the conurbations of Greater Manchester and Liverpool, in addition to the seasonally increased nearby residential heating activities, made this site a receptor for pollutants from a range of sources. A factor analysis is applied to the mass spectra of organic matter (OM) measured by the Aerodyne Aerosol Mass Spectrometer (AMS) to attribute the pollutant sources. Besides the oxygenated organic aerosol (OOA), this site was found to contain a considerable fraction of primary organic aerosols (POA, mass fraction 50-70\% within total mass of OM). The POA sources are attributed to be traffic emission and solid fuel burning, which are identified as hydrocarbon-like organic aerosol (HOA) and solid fuel organic aerosol (SFOA) respectively. There were strongly combined emissions of black carbon (BC) particles from both sources. The refractory BC component (rBC) was characterized by a single particle soot photometer. This site began to be influenced during the late morning by fresh traffic emissions, whereas solid fuel burning became dominant from late afternoon until night. A covariance analysis of $\mathrm{rBC}$ and $\mathrm{POA}$ was used to derive source specific emission factors of $1.61 \mu \mathrm{gHOA} / \mu \mathrm{grBC}$ and $1.96 \mu \mathrm{gHOA} / \mu \mathrm{grBC}$. The absorbing properties of aerosols were characterized at multiple wavelengths $(\lambda)$, and a stronger spectral dependence
\end{abstract}

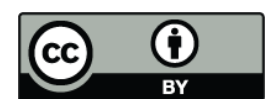

Correspondence to: D. Liu (dantong.liu@manchester.ac.uk) of absorption was observed when this site was significantly influenced by solid fuel burning. The rBC was estimated to contribute $3-16 \%$ of submicron aerosol mass. The single scattering albedo at $\lambda=700 \mathrm{~nm}\left(\mathrm{SSA}_{700 \mathrm{~nm}}\right)$ was significantly anti-correlated with the $\mathrm{rBC}$ mass fraction, but also associated with the $\mathrm{BC}$ mixing state. The $\mathrm{BC}$ incorporation/removal process therefore may play a role in modulating the radiative properties of aerosols at the site under the influence of fresh sources. Given that traffic and residential combustion of solid fuels are significant contributors of carbonaceous aerosols over Europe, these results provide important source-specific information on modeling the anthropogenic carbonaceous aerosols.

\section{Introduction}

Particles have long been known to significantly influence air quality and climate and to originate from a variety of sources. Primary aerosols are emitted directly into the atmosphere but undergo transformation in the atmosphere during transport. Secondary material is added both as additional mass to existing particles and through the formation of secondary aerosols. Recent studies on the source attribution of sub-micron aerosols have been primarily focused on the investigation of the organic fraction as individual organic compounds can be used as markers for certain sources (Rogge et al., 1993). The Aerodyne Aerosol Mass Spectrometer (AMS) provides detailed information on the mass spectra of aerosols with high time resolution (Canagaratna et al., 2007). The organic aerosol (OA) mass spectra obtained from AMS measurements is often incorporated

Published by Copernicus Publications on behalf of the European Geosciences Union. 
into analysis mechanisms to identify the general classes of OA. Techniques such as Multiple Component Analysis (MCA, Zhang et al., 2005, 2007) have been used to separate the measured signal as either hydrocarbon-like or oxygenated organic aerosol (HOA or OOA), which are broadly attributed to primary organic aerosol (POA) or secondary organic aerosol (SOA), respectively. A more recent methodology, positive matrix factorization (PMF, Paatero, 1997) has been applied to a variety of polluted environments to identify sources that are beyond the classifications of HOA and OOA, for example, the OOA can be further distinguished according to the extent of its oxidization (Lanz et al., 2007; Ulbrich et al., 2009) and volatility (Huffman et al., 2009), and the broadly classified HOA (or POA) can be further attributed to different sources (Lanz et al., 2007; Allan et al., 2010).

Besides the OA, black carbon aerosol (BC) also contributes to carbonaceous particulate mass, furthermore $\mathrm{BC}$ is highly light absorbing (Bond and Bergstrom, 2006) and has been revealed to significantly perturb the radiative balance of the solar-earth system causing a range of regional impacts (Ramanathan and Carmichael, 2008). The relationship between $\mathrm{BC}$ and $\mathrm{OA}$ has been widely used to diagnose the ageing of sources as $\mathrm{BC}$ is conserved after emission other than through wet removal, whilst SOA greatly increases the OA mass with time (Chu 2005 and references therein). The emission of $\mathrm{BC}$ is concurrent with the other combustion species, such as $\mathrm{HOA}$ and trace gasses (e.g. $\mathrm{CO}, \mathrm{NO}_{\mathrm{x}}$ ). However, fresh OA undergoes gas phase repartitioning (Robinson et al., 2007) and is photochemically processed becoming more oxidized with time ( $\mathrm{Ng}$ et al., 2010) and less volatile (Huffman et al., 2009) as distance from the source increases (Jimenez et al., 2009). Ageing of aerosol often changes the hygroscopicity of the particles, thus affecting their atmospheric lifetime by modifying the efficiency of wet removal. However the information is still sparse with respect to the modification of BC hygroscopic properties (Koch et al., 2009). Recently, studies on the evolution and ageing time of $\mathrm{BC}$ in the atmosphere became possible by examining its mixing state utilizing the single particle photometer instrument (SP2, manufactured by Droplet Measurement Technologies, Boulder, USA; e.g. Schwarz et al., 2006). A better understanding of the BC mixing state is of great importance for modeling its lifetime in the atmosphere.

The previous thermo-optical measurements of $\mathrm{BC}$ introduce ambiguities in the models of $\mathrm{BC}$ as a result of systematic instrument uncertainties and the variety of $\mathrm{BC}$ definitions which are related to specific measurement techniques (Andreae and Gelencsér, 2006; Bond and Bergstrom, 2006). In addition, the characteristics of $\mathrm{BC}$ are not widely treated as source specific in the modeling community, although BC has been observed to show different properties when emitted from different sources (Schwarz et al., 2008). The main sources of carbonaceous aerosols in Europe are emissions from traffic and residential combustion of solid fuels (Kupiainen and Klimont, 2007) and it is their emission and spatial and temporal variation that lead to the largest uncertainties in modeling the BC over Europe (Tsyro et al., 2007).

The contribution from residential combustion is higher during the winter time due to the usage of domestic heating, whereas the seasonal variation is small for vehicle emission sources. In a pan-European study, the northwest of England (in common with similar large urban areas) has been demonstrated to be a large source of carbonaceous aerosols (Tsyro et al., 2007). The pollutants in central Manchester during the winter and autumn seasons have been found to contain significant contributions from traffic emissions and biomass burning, such as would be emitted by solid fuel burning (Allan et al., 2010).

This study is based on measurements made at a polluted rural site, Holme Moss, which is located in the southern Pennines region in Northwestern England, approximately $30 \mathrm{~km}$ to the northeast of the city of Manchester. The experiment was conducted during November-December 2006, when the ambient temperature was low and localized residential heating sources were prevalent. The synoptic cyclonic flows resulted in strong south-westerly flow during the experiment, allowing the transport of pollutants from the Greater Manchester conurbation (population approximately 2.5 millions). As a result, this site tended to be influenced by combined sources. PMF analysis is applied to the mass spectra of organic aerosols measured by the AMS to attribute the OA and this characterization was used to investigate the physical and optical properties of $\mathrm{BC}$ from the different sources.

\section{Experimental}

\subsection{Site description and meteorological conditions}

The Holme Moss site is positioned in the rural southern Pennines of Northern England at an altitude of $525 \mathrm{~m}$ a.s.l. (geographical coordinate $53.53^{\circ} \mathrm{N}, 1.86^{\circ} \mathrm{W}$ ), approximately $30 \mathrm{~km}$ to the northeast of the city of Manchester (Fig. 1). The site is described in detail by Beswick et al. (2003). The experimental period lasted from 7 November 2006 to 4 April 2006, during which time the locally monitored wind speed was 10 to $15 \mathrm{~m} \mathrm{~s}^{-1}$, and the wind direction was from the southwest for $90 \%$ of the time (Fig. 1). This led to efficient transport of urban pollutants from the Greater Manchester conurbation to the site. In addition, the site is in close proximity to several small towns, where the burning of wood, coke, coal and anthracite for domestic space heating is widespread in the winter (NAEI, 2009), although the solid fuel burning that produces smoke is legislated against in most metropolitan areas in the UK, which includes most Greater Manchester areas (Smoke Control Areas, 2009). This meant the site was significantly influenced by primary pollutants from combined sources. The weak incident solar radiation, the low temperature in the winter, as well as the frequent cloud cover, made photochemical processing less efficient during the experimental period. 


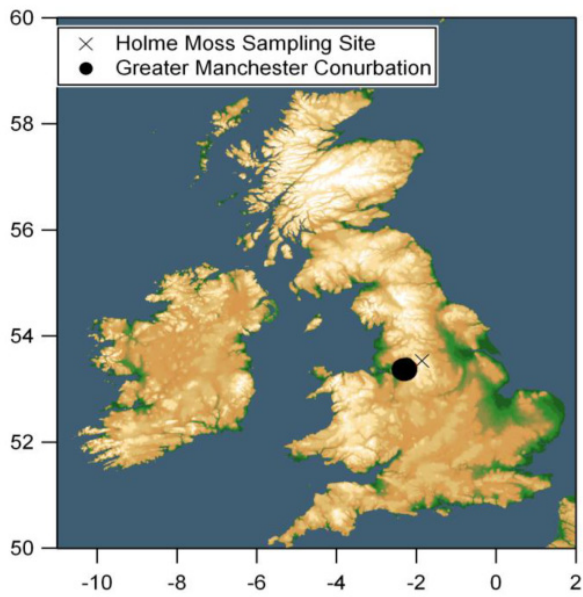

A

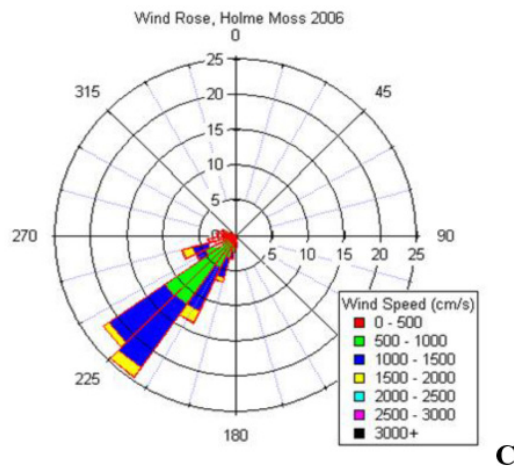

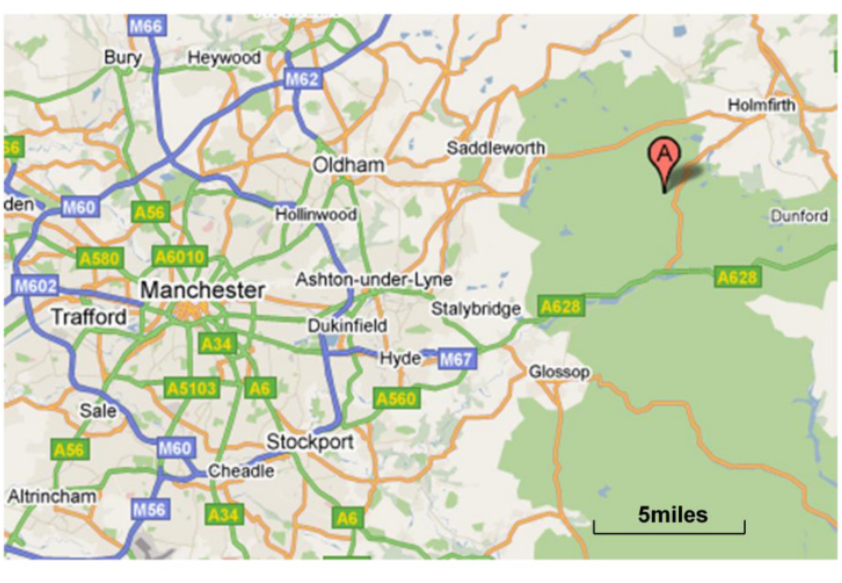

B

Fig. 1. (A) The approximate location of the Greater Manchester conurbation area and Holme Moss site are shown in the UK map (download from http://edc.usgs.gov/) marked with black solid dot and cross respectively. (B) The detailed map of the Greater Manchester conurbation area (download from http://maps.google.co.uk/) showing the primary arterial roads. The Holme Moss sampling station is marked as red letter A on the upper right side of this map. (C) The wind rose shows the frequency distribution of hourly averaged wind direction and speed throughout the experimental period.

\subsection{Instrumentation, sampling and data analysis methodology}

\subsubsection{Sampling inlet}

The inlet system was comprised of a plastic stack with a height of $\sim 10 \mathrm{~m}$, the inner diameter of which was about $21.4 \mathrm{~cm}$, through which a total flow of $\sim 1000 \mathrm{~L} \mathrm{~min}^{-1}$ was pulled. A $2.44 \mathrm{~m}$ long stainless steel tube with an inner diameter of approximately $4.7 \mathrm{~cm}$ was used to subsample $150 \mathrm{~L} \mathrm{~min}^{-1}$ isokinetically from the centreline of the flow inside the stack. This inlet system has been previously described by Sheridan et al. (2001), who quotes a collection efficiency for particles between 0.01 and $1 \mu \mathrm{m}$ of over $95 \%$. The loss rate rises to $10 \%$ for particles larger than $10 \mu \mathrm{m}$. A $5 \mu \mathrm{m}$ impactor is used to prevent the sampling of larger aerosols and cloud droplets, thus when cloud is present at the site the sampled particles are interstitial aerosol rather than droplet residuals. Downstream of the impactor the airflow is isokinetically split between the instrumentation located in temperature controlled container laboratories.

\subsubsection{Physiochemical properties of aerosols}

\section{Non-refractory particle composition}

The time resolved chemical mass loadings and distributions of key submicron non-refractory components of the aerosol were measured by an Aerodyne compact Time of Flight Aerosol Mass Spectrometer (cToF-AMS) (Canagaratna et al., 2007; Drewnick et al., 2005). In addition the cToF-AMS delivers time series of component mass spectra. Positive matrix factorization (PMF) was used to investigate the organic mass spectral profiles. PMF seeks to represent the measured data by a linear superposition of a number of unchanging mass spectral profiles as factors, and the contribution from 
each profile to the measured data as a function of time can be determined (Paatero, 1997; Lanz et al., 2007). The profiles of factors represent mass spectra and the changing contributions capture the variation of mass loadings to determine the varying relative contributions from each type which may be linked to a source.

The PMF analysis performed as part of this work used the PMF Evaluation Toolkit (PET), as introduced by Ulbrich et al. (2009). The organic matrix was extracted using the fragmentation table method described by Allan et al. (2004) and the error model of Allan et al. (2003) was used. Rather than use downweighting, the predicted contributions to the water signal (principally $m / z=18$ ) were removed before processing and mass concentrations scaled up accordingly afterwards. As with all PMF analysis, a degree of ambiguity exists due to the finite number of factors chosen and rotational freedom between the different solutions. Similar criteria to those used by Allan et al. (2010) were employed in the selection of an optimal solution set, whereby solutions were tested according to the uniqueness of factors and numerical stability of the solutions. In the absence of sufficient external data to constrain rotationality between solutions, the value of the FPEAK parameter was selected based on the uniqueness of the time series derived and the optimum $Q$ value found. Full details on the selection of the solution are contained within the supplementary material.

\section{Optical properties}

An integrating nephelometer (Model 3563, TSI, Shoreview, $\mathrm{MN}$, USA.) was used to measure the total scattering coefficient $\left(\sigma_{\mathrm{sp}}\right)$ at 450,550 and $700 \mathrm{~nm}$ simultaneously (Anderson et al., 1996), from which the data was corrected for truncation errors following the procedures recommended by Anderson and Ogren (1998). The absorption coefficient $\left(\sigma_{\mathrm{ap}}\right)$ was determined using a three-wavelength Particle Soot Absorption Photometer (PSAP) at $\lambda=467,530$ and $660 \mathrm{~nm}$ (Radiance Research, Seattle, WA, USA). The data were corrected for the scattering artifact and departures from manufacturer defaults (e.g., spot size and flow rate) according to Bond et al. (1999). The spectral dependence of absorbing properties is investigated by calculating the absorption Ångström coefficient $\left(\stackrel{\circ}{a p}_{\text {ap }}\right)$ as expressed by Eq. (1):

$\stackrel{\circ}{a}_{\text {ap }}=\frac{\ln \left(\sigma_{660 \mathrm{~nm}} / \sigma_{467 \mathrm{~nm}}\right)}{\ln (467 / 660)}$

The optical absorption of bulk aerosols was also monitored with a Model 5012 Multi-Angle Absorption Photometer (MAAP) at $\lambda=670 \mathrm{~nm}$ (Thermo Fisher Scientific Inc., Waltham, MA, USA) The MAAP simultaneously measured the transmission and back scattering of a light beam through a glass fibre filter onto which the aerosol is sampled continuously. $\sigma_{\text {ap }}$ is obtained from a radiative transfer scheme which corrects for artefacts caused by the interaction of the light with the filter material and off-axis detection at multiple angles is used to correct for the effect of scattering (Petzold and Schönlinner, 2004). The $\sigma_{\text {ap }}$ presented in this paper is corrected to standard temperature and pressure (STP; $273.15 \mathrm{~K}, 1013.25 \mathrm{hPa}$ ).

\section{Refractory BC particles (rBC)}

The physical properties of single refractory $\mathrm{BC}$ particles (rBC) were characterized by the single particle soot photometer (SP2). This instrument uses an intra-cavity Nd:YAG laser at $1064 \mathrm{~nm}$ to determine the size of a single particle by light scattering and quantify its $\mathrm{rBC}$ mass by detection of the incandescence radiation if the particle absorbs at the laser wavelength (Stephens et al., 2003; Baumgardner et al., 2004). In this study, the incandescence signal was calibrated using commercially available standard glassy carbon spheres (supplied by Alpha Aesar, Inc.,Ward Hill, Massachusetts, with density $1.42 \mathrm{~g} \mathrm{~cm}^{-3}$ ), which were size-selected using a differential mobility analyzer (DMA) upstream of the SP2 down to single particle mass loadings of about $12 \mathrm{fg}$ (mobility diameter $250 \mathrm{~nm}$ ). Mono-dispersed polystyrene latex spheres of known sizes were used to calibrate the scattering signal. The operation, calibration and data analysis methods for the Manchester SP2 instrument during the experiment are described by Liu et al. (2010), and the instrument configuration in this study is identical to the descriptions in that paper. The instrument determined $\mathrm{rBC}$ mass between 6-240 fg during this experiment, which is equivalent to the diameter range of $190-650 \mathrm{~nm}$ assuming the particle to be a solid sphere with density of $1.9 \mathrm{gcm}^{-3}$ (Bond and Bergstrom, 2006). To account for the rBC mass below the SP2 lower detection limit, previous studies have estimated the total $\mathrm{rBC}$ by extrapolating the mass size distribution based on a single lognormal mode (Schwarz et al., 2006). This methodology has also been applied for our instrument, which is described in detail in Liu et al. (2010), where about $40-60 \%$ mass of the entire rBC population has been detected by the SP2. The mass of $\mathrm{rBC}$ presented in this paper has been corrected for these effects. Scattering particles were optically sized between 220-720 $\mathrm{nm}$ diameter.

The SP2 is capable of providing information on the mixing state of $\mathrm{rBC}$ by measurement of the delay time between the scattering and incandescence signals that is commonly referred to as the coating evaporation time. The SP2 can also be used to estimate the $\mathrm{rBC}$ mass fraction within a single particle for a coated rBC (Liu et al., 2010). A thicker coating on an $\mathrm{rBC}$ particle tends to increase the time delay and decrease the $\mathrm{rBC}$ mass fraction. In this study, a frequency distribution of delay times and mass fractions of detected $\mathrm{rBC}$ particles displayed a bimodal distribution. The minimum between the two modes was observed to occur at a time delay of $4.6 \pm 0.2 \mu$ s and a rBC mass fraction of 0.75 with approximate coating thickness of $50 \pm 15 \mathrm{~nm}$. Particles with time delays in excess of this value and mass fraction less than this threshold are termed as thickly-coated BC. The mixing 


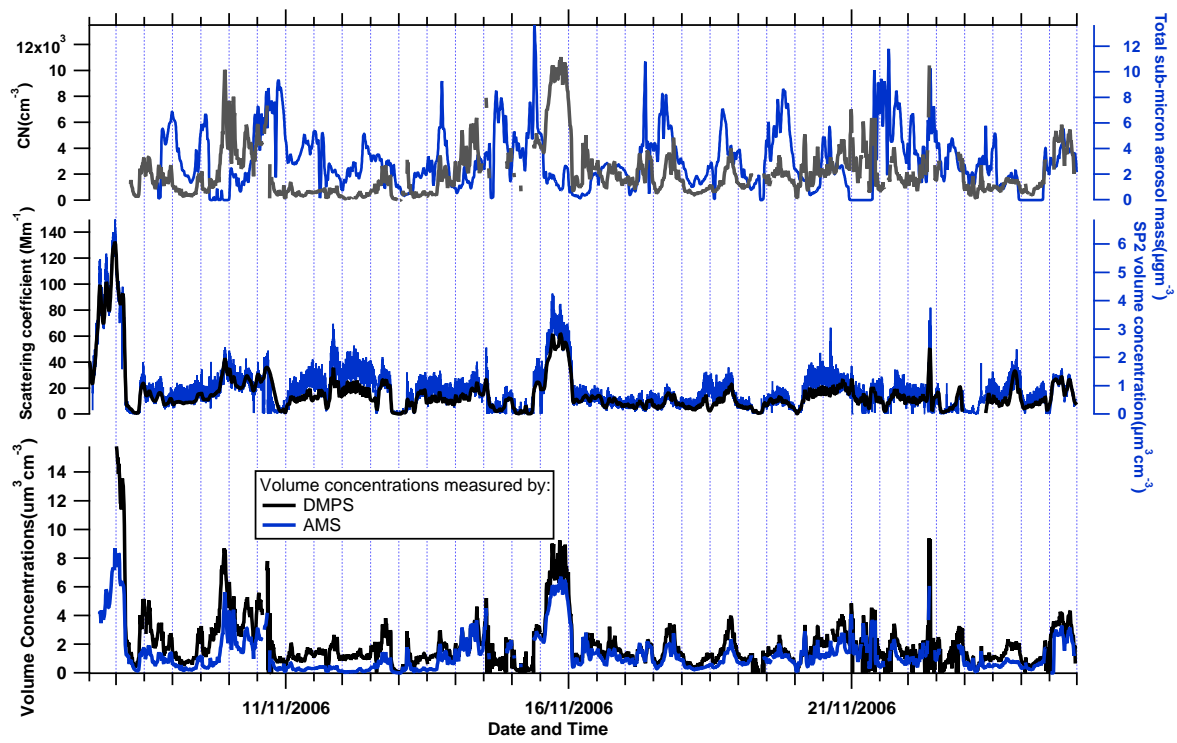

Fig. 2. The time series (from top to bottom) of $\mathrm{CN}$ concentration with the right axis showing the total sub-micron aerosol mass loading; the submicron scattering coefficient measured by nephelometer (at $\lambda=550 \mathrm{~nm}$ ) with the right axis showing the SP2 optically measured volume concentration; the total volume concentrations derived from AMS (by assuming densities of 1.27 and $1.77 \mathrm{~g} \mathrm{~cm}^{-3}$ for organics and inorganic aerosol respectively) and DMPS measurement.

efficiency of $\mathrm{BC}$ is defined as the number fraction of thicklycoated BC particles.

The total mass of submicron aerosol is calculated as the sum of AMS measured non-refractory aerosol mass (sulfate + nitrate + ammonia + chloride + organic) and SP2 measured refractory BC mass. In addition to the instruments above, a Differential Mobility Particle Sizer (DMPS) was used to measure the aerosol mobility diameter between 25$740 \mathrm{~nm}$, as fully described by Williams (1999). A Condensation Particle Counter (CPC, TSI 3010 model) measured the condensation nucleus $(\mathrm{CN})$ concentration of all sub-micron aerosols with a diameter greater than $10 \mathrm{~nm}$.

\section{Results}

\subsection{Total aerosol loadings}

The AMS volume concentration (down to about aerodynamic diameter $60-70 \mathrm{~nm}$ ) was derived from the measured non-refractory aerosol mass by assuming densities of 1.27 and $1.77 \mathrm{~g} \mathrm{~cm}^{-3}$ for organics and inorganic aerosol respectively (Cross et al., 2007). The differential mobility particle sizer (DMPS) measured mobility diameter at $25-740 \mathrm{~nm}$, from which the volume concentration was estimated assuming spherical aerosols. The SP2 optically sizes the scattering particles between $220-720 \mathrm{~nm}$ diameter. Figure 2 summarizes the volume concentrations measured by the different instruments, total mass of submicron aerosols and $\mathrm{CN}$. The time series of volume concentrations for each instrument and the total aerosol mass are well correlated with $\sigma_{\mathrm{sp}}$ measured by the nephelometer $\left(r^{2}>0.7\right)$. The AMS volume is equal to or less than the DMPS volume owing to the insensitivity of the AMS to refractory particles that cannot be vaporized at $\sim 600{ }^{\circ} \mathrm{C}$, such as $\mathrm{BC}$ or some refractory organic aerosols.

At this site, a diurnal variation of pollution was expected due to the local variability in emissions. The diurnal evolution of the aerosol is shown in Fig. 3. The $\mathrm{CN}$ population was dramatically elevated from 10:00 until 20:00 and reduced during the night. The total aerosol mass and aerosol scattering coefficient both showed a much weaker diurnal variation as compared to the $\mathrm{CN}$. This is because the smaller Aitken mode particles, i.e. freshly formed through nucleation processes, dominate the aerosol number (e.g. Kittelson, 1998) but contribute little to the total mass and are less efficient at light scattering compared to the larger accumulation mode particles. The enhancement of CN from 10:00-20:00 and its correlation with $\mathrm{BC}$ indicates fresh sources contributing to the particle load at the site.

\subsection{Source attribution by PMF analysis}

\subsubsection{Classification of PMF factors}

Figure $4 \mathrm{a}$ shows the mass spectra for the retrieved three factors from PMF analysis. The Oxygenated Organic Aerosol (OOA) is identified as such due to its strong peak at $m / z 44$ (Zhang et al., 2005). This type of organic aerosol has been widely reported as "type 1 " OOA, representing aged secondary organic aerosols (Lanz et al., 2007; McFiggans et al., 2005). The Hydrocarbon-like Organic Aerosol (HOA) agrees with previously reported mass spectra associated with 


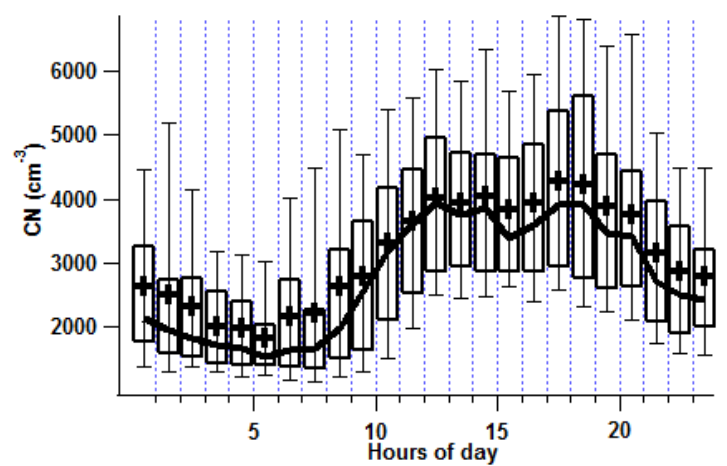

A

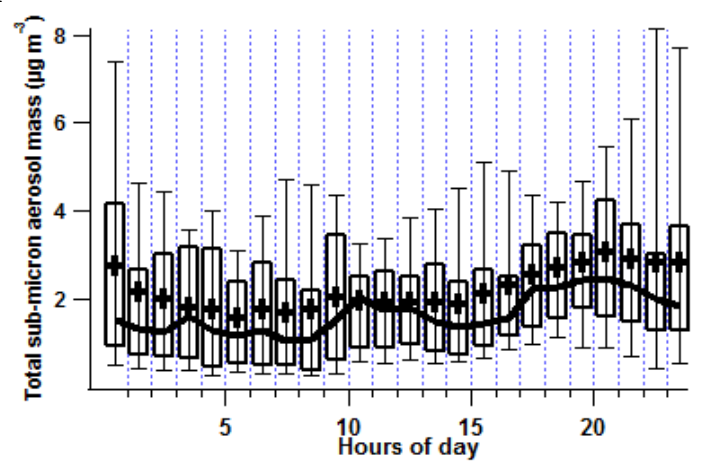

B

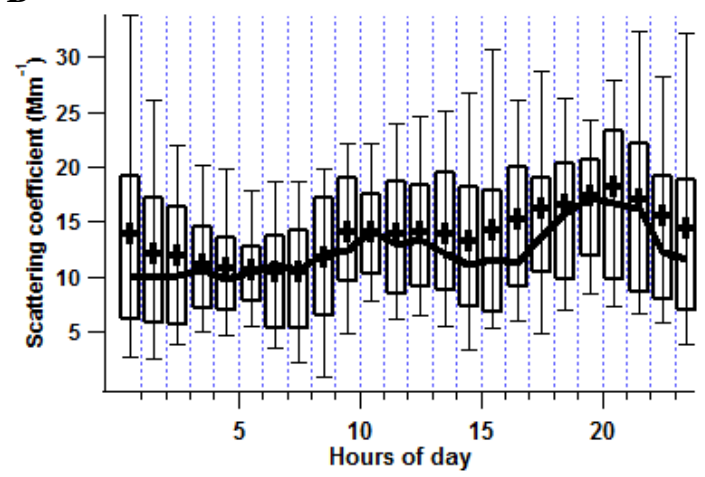

C

Fig. 3. The diurnal variations (from top to bottom) of $\mathrm{CN}\left(\mathrm{cm}^{-3}\right)$, total submicron aerosol mass $\left(\mu \mathrm{g} \mathrm{m}^{-3}\right)$ and sub-micron scattering coefficient $\left(\mathrm{Mm}^{-1}\right)$. The upper and lower edges of the box denote the $25 \%$ and $75 \%$ percentiles respectively. The lines in the middle of box and cross markers indicate the median and average values respectively, with error bars explaining the $10 \%$ and $90 \%$ percentiles.

vehicle exhaust emissions (Canagaratna et al., 2004; Schneider et al., 2005), showing the largest peak at $\mathrm{m} / \mathrm{z} 43$ and 57, in addition to the characteristic peaks at 41, 43, 55 and 57 with weak signal at 44. The factor Solid Fuel Organic Aerosol (SFOA) has some $m / z$ signals similar to HOA $(55,57,69$, 71) and a notable signal at $m / z 60$, a typical indicator of levoglucosan, which is the thermal decomposition product of cellulose. The levoglucosan is often a typical tracer for the organic aerosol from biomass burning (Jordan et al., 2006;
Table 1. A summary of Pearson correlation coefficient $\left(r^{2}\right)$ between different components of the organic particles and other particulate components. $r^{2}$ values over 0.50 are highlighted in bold.

\begin{tabular}{lclc}
\hline$r^{2}$ & OOA & HOA & SFOA \\
\hline $\mathrm{NO}_{3}$ & $\mathbf{0 . 6 4}$ & 0.38 & 0.26 \\
$\mathrm{SO}_{4}$ & $\mathbf{0 . 5 3}$ & 0.15 & 0.22 \\
Total inorganic & $\mathbf{0 . 7 3}$ & 0.30 & 0.29 \\
rBC & 0.30 & $\mathbf{0 . 6 0}$ & $\mathbf{0 . 5 2}$ \\
\cline { 3 - 4 } & & $\mathbf{0 . 7 2}$ (bilinear fitting) \\
\hline
\end{tabular}

Simoneit, 2002) as has been evidenced via the AMS measurement in both ambient and laboratory spectra (Capes et al., 2008; Schneider et al., 2006; Alfarra et al., 2007). A recent study by Allan et al. (2010) investigating the primary organic aerosols in the two UK cities Manchester and London attributes the urban sources as vehicle emission (HOA), solid fuel burning (SFOA) and cooking organic aerosol (COA). There is little evidence of COA at the Holme Moss site but both SFOA and HOA are significant factors that have distinctly different diurnal profiles due to the location of the sample site relative to the sources. It is possible that there are other minor contributions to primary organic aerosol (POA) but these were not resolved by the PMF analysis.

\subsubsection{Interpretations of PMF factors}

\section{Primary aerosols}

In common with other studies (Zhang et al., 2007 and references therein), the factors HOA and SFOA can be interpreted as POA (POA mass $=$ HOA mass + SFOA mass) and should therefore be correlated with other primary combustion emissions, such as $\mathrm{BC}$; whereas the OOA has a signature of secondary aerosols, which has been revealed to have correlations with aerosol attributed to secondary species, such as sulphate and nitrate. Figure $4 \mathrm{~b}$ shows the time series for the three PMF factors and identifies species that temporally correlate with the organic factors. Table 1 summarizes and indicates the high correlations in bold text. There is a positive correlation between $\mathrm{rBC}$ mass and both HOA and SFOA, with Pearson correlation coefficients 0.60 and 0.52. A bilinear function is used to fit the $\mathrm{rBC}$ mass simultaneously with both HOA and SFOA as expressed in Eq. (1):

$$
\begin{aligned}
& f_{\mathrm{BC}}(\mathrm{HOA}, \mathrm{SFOA})=a[\mathrm{HOA}]+b[\mathrm{SFOA}]+c \\
& a=0.62 \pm 0.014 \mu \mathrm{grBC} / \mu \mathrm{gHOA} \text { or } 1.61 \mu \mathrm{gHOA} / \mu \mathrm{grBC} \\
& b=0.51 \pm 0.009 \mu \mathrm{grBC} / \mu \mathrm{gHOA} \text { or } 1.96 \mu \mathrm{gHOA} / \mu \mathrm{grBC} \\
& c=0.025 \\
& r_{(\mathrm{BC}-\mathrm{HOA}-\mathrm{SFOA})}^{2}=0.72
\end{aligned}
$$




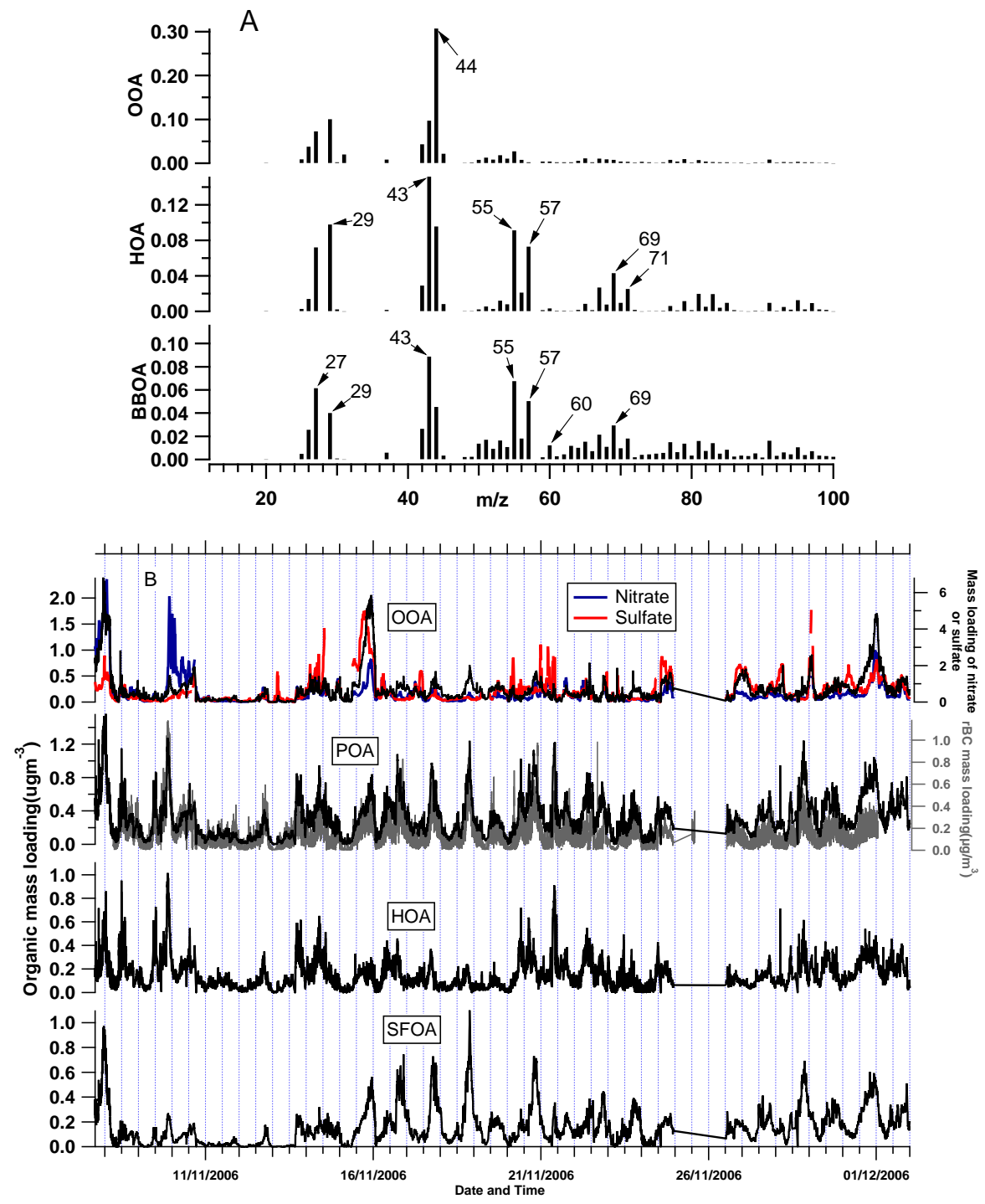

Fig. 4. (A) Results of PMF analysis, showing the time series and mass spectra for the three factor solution. The factors are identified as OOA, HOA and SFOA. (B) From top to bottom: time series of OOA along with the nitrate and sulfate shown on the right y-axis; POA (the sum of HOA and SFOA) with rBC mass loading shown on the right y-axis; HOA and SFOA.

Using bilinear fitting improves the correlation coefficient with $\mathrm{rBC}(0.72)$ compared to that with the individual factors. This is a strong indication that the $\mathrm{rBC}$ loadings have both urban transport pollution and solid fuel burning sources. The emission factors of $0.62 \pm 0.014 \mu \mathrm{grBC} / \mu \mathrm{gHOA}$ and $0.51 \pm 0.009 \mu \mathrm{grBC} / \mu \mathrm{gSFOA}$ are derived from this bilinear regression. The $\mathrm{rBC}$ emitted along with $\mathrm{HOA}\left(\mathrm{rBC}_{\mathrm{HOA}}\right)$ or SFOA $\left(\mathrm{rBC}_{\mathrm{SFOA}}\right)$ can therefore be estimated by the emission rates derived here.

The diurnal cycles of primary aerosols are shown in Fig. 5 . The morning peak of HOA occurs between 10:00 and 12:00 with average loading of $0.2 \mu \mathrm{g} \mathrm{m}^{-3}$, in a similar manner to the diurnal cycle in total CN. Allan et al. (2010) reported a HOA morning peak loading of $4.6 \mu \mathrm{g} \mathrm{m}^{-3}$ between 07:00 and 09:00 in the urban area of Manchester coinciding with the traffic rush hour. Compared to the Manchester results, the HOA peak loading in the Holme Moss site was considerably lower and the morning occurrence of the peak urban pollution at the Holme Moss site, was delayed for about 1-2 hours. This is consistent with advection times from Manchester urban centre $(\sim 25 \mathrm{~km})$ according to the average local wind speeds (10-13 $\left.\mathrm{m} \mathrm{s}^{-1}\right)$ and direction during the experiment. The average mass loading and the morning peak of HOA are both significantly reduced at weekends (grey lines in Fig. 5a), which would be expected given the reduced traffic.

The majority of previous urban studies showed a reduced pollution loading after the morning rush hour peak 


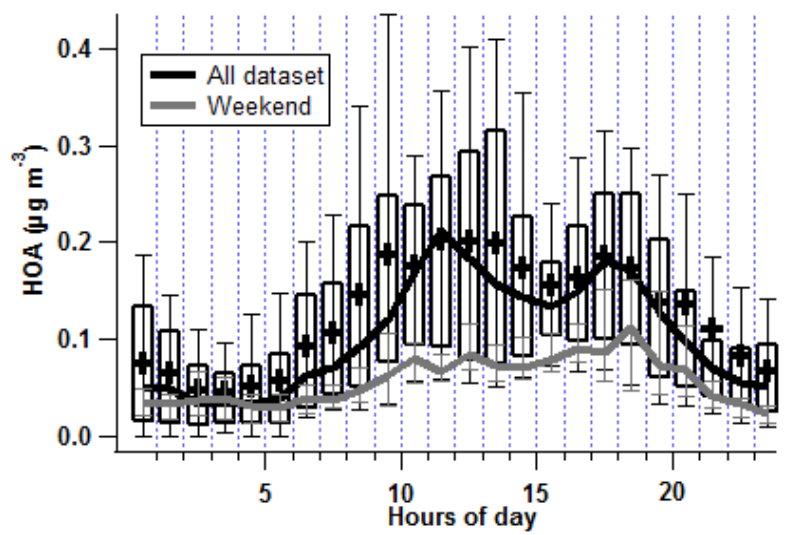

A
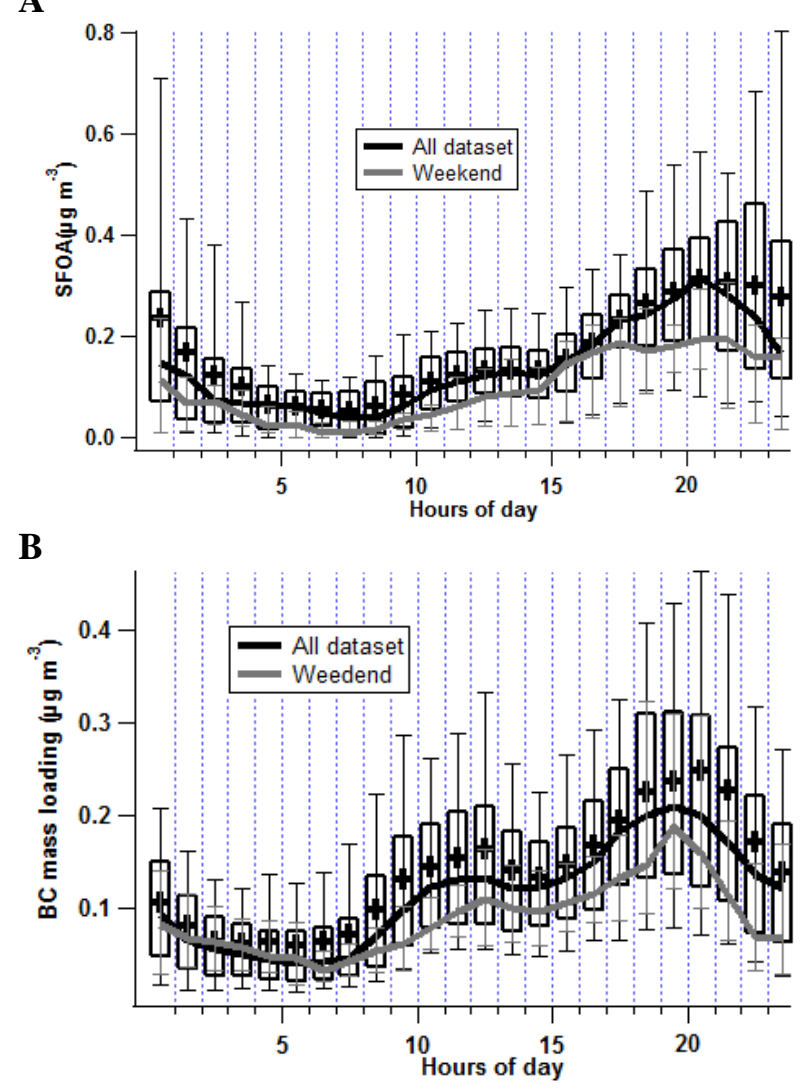

C

Fig. 5. Average diurnal cycles (from top to bottom) of HOA, SFOA and $\mathrm{rBC}$ mass. The black and grey lines show the entire dataset and weekend only data respectively. The grey lines show the median value associated with the error bars denoting $25 \%$ and $75 \%$ percentiles. The markers on the black line have the same meaning as in Fig. 3.

concentration due to elevated boundary layer heights and increased mixing volume typical of later in the day (e.g. Allan et al., 2010; Baumgardner et al., 2007; Kondo et al., 2006). In this study, the HOA loading reduced only slightly after the morning peak and significantly increased to $0.18 \mu \mathrm{g} \mathrm{m}^{-3}$ between 16:00-18:00, comparable in magnitude to the morning peak at the Holme Moss site. These differences are likely to be due to meteorological differences experienced over the complex terrain.

The SFOA loading at the Holme Moss site (Fig. 5b) tended to rise significantly from 16:00 and began to decrease after midnight. This diurnal trend is similar to the Manchester urban results (Allan et al., 2010), because in the winter most burning for space heating occurs in the late evening. The lack of a delay suggests the SFOA observed at this site is from local towns rather than Greater Manchester. The nocturnal inversion at night will trap the pollutants and further increase the pollutant concentration, as the high outliers in Fig. 5b show.

Wood is commonly used as a space heating fuel in the UK (NAEI, 2009). Although the solid fuel burning that produces smoke is legislated against in most metropolitan areas in the UK, which includes most of Greater Manchester (Smoke Control Areas, 2009), the practice of seasonal burning smoking fuels such as wood in open fires is still widespread in the rural areas surrounding Manchester including those around Holme Moss site. Other solid fuels such as coal, anthracite and smokeless fuels are also strong contributors (NAEI, 2009), warranting the term of SFOA for the organic aerosol produced from this sector.

The diurnal variability of $\mathrm{rBC}$ loadings (Fig. 5c) clearly shows contributions from both HOA and SFOA, exhibiting double peaks. The maximum morning loading of $150 \pm 30 \mathrm{ng} \mathrm{m}^{-3}$ occurred at 11:00-13:00 and was coincident with the HOA peak. The evening peak occurred between 18:00 and 21:00, and had a peak loading of 270 \pm $50 \mathrm{ng} \mathrm{m}^{-3}$. The earlier part of this evening peak was coincident with the peak in HOA and hence was likely to arise from vehicle emission and the latter was coincident with the peak in the organic matter from solid fuel burning.

\section{Secondary aerosols}

The OOA represents the contribution of aged, oxidised secondary organic material to the particulate mass, and has previously been shown to be correlated with inorganic secondary species such as nitrate and sulfate (Lanz et al., 2007; Zhang et al., 2007). However, correlations between OOA and inorganic secondary species will depend on the relative similarities of distribution of precursor emissions and formation processes. The OOA in this study correlates significantly with total measured inorganic particulate mass $\left(r^{2}=0.73\right.$, Table 1), and is better correlated with nitrate $\left(r^{2}=0.64\right)$ than sulfate $\left(r^{2}=0.53\right)$. Allan et al. (2010) observed that the OOA showed a higher correlation with nitrate than sulphate when the OOA was less oxidized, especially in the winter time, which may explain the greater correlation of OOA with nitrate than sulfate in this study, given the low photochemical activity and a lack of volatile organic precursors during the experimental period. 


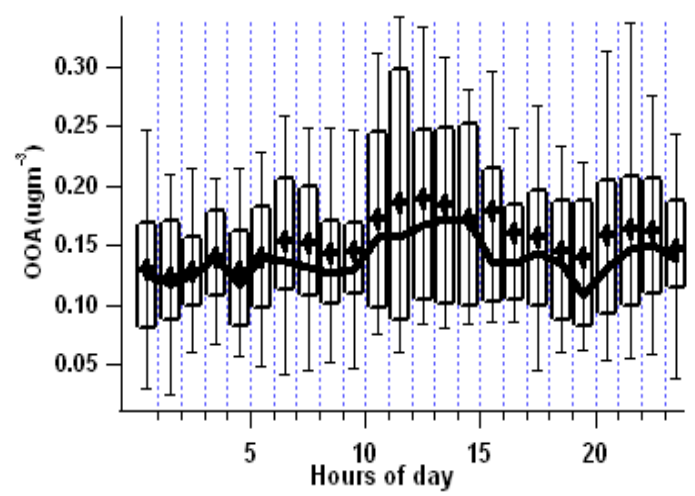

A

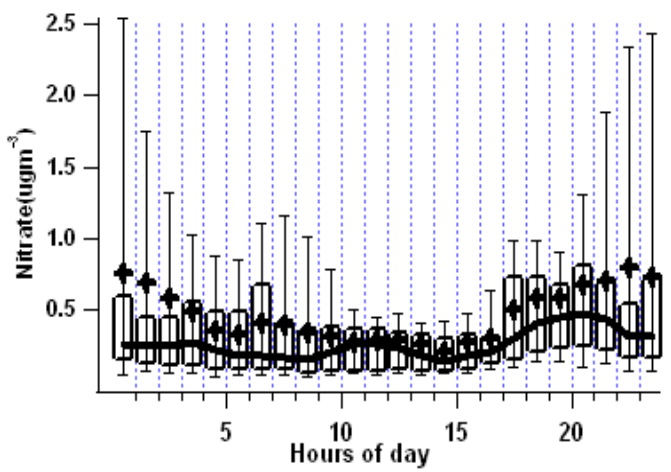

B

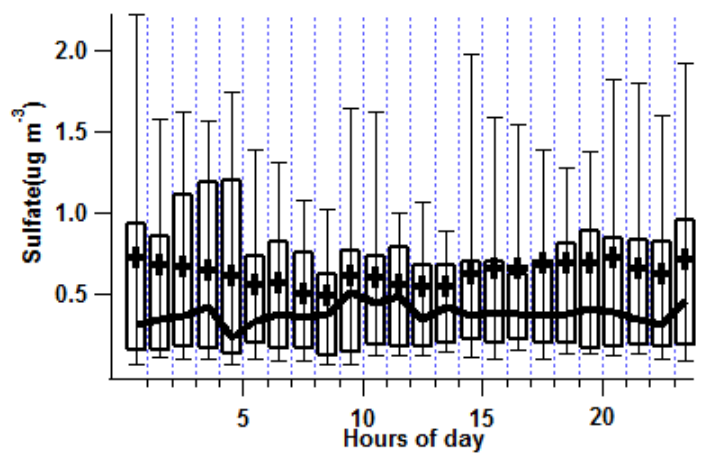

C

Fig. 6. Average diurnal cycles (from top to bottom) of OOA, nitrate and sulphate.

The OOA shows no obvious diurnal variability (Fig. 6), indicating that it represents the regional background as has been observed in other studies (Lanz et al., 2007; Ulbrich et al., 2009). The mean value of sulfate concentration is higher than the median value, indicating the presence of elevated sulfate was intermittent. The nitrate has large outliers at night, as the ammonium nitrate equilibrium with its precursor gases ammonia and nitric acid is heavily modulated by temperature and humidity (Morino et al., 2006; Morgan et al., 2010). Note that unlike some previous studies, the OOA could not be separated into low- and semi-volatile components (Jimenez et al., 2009). In common with the winter and autumn studies presented by Allan et al. (2010), this was probably because there was not a large enough variation in temperature experienced $\left(6 \pm 2.5^{\circ} \mathrm{C}\right)$ to separate the two components.

\subsection{The optical properties of aerosols}

This site was under the influence of both urban outflow and residential solid fuel burning, and hence substantial amounts of absorbing particles were present. Besides the highly absorbing BC (Bond and Bergstrom, 2006), some organic aerosols, known as brown carbon, will also contribute significantly to light absorption when present in high abundance, especially under the influence of biomass burning (Andreae and Gelenesér, 2006, and references therein). Given that Holme Moss received considerable particulate matter from solid fuel burning sources, the absorption by brown carbon could also be an important constituent of measured light absorption.

The presence of brown carbon introduces a bias in BC mass determinations by absorption methods at shorter wavelengths which are variable depending on the abundance of absorbing organic matter (Andreae and Gelenesér, 2006; Lack et al., 2008). The picture is further complicated because of the different spectral dependence of absorption for $\mathrm{BC}$ and organic carbon. Organic carbon absorption increases sharply towards lower wavelengths, making their absorption in the UV potentially more significant than that of BC. It is therefore preferable to characterize absorption using multiple $\lambda \mathrm{s}$ in environments with high loadings of both $\mathrm{BC}$ and brown carbon.

The absorbing properties during this study were characterized at multiple $\lambda \mathrm{s}$ (PSAP $467 \mathrm{~nm}, 530 \mathrm{~nm}, 660 \mathrm{~nm}$ and MAAP $670 \mathrm{~nm}$ ), as shown in Fig. 7a, and are unsurprisingly highly correlated $\left(r^{2}>0.93\right)$. In common with previous studies (Bond and Bergstrom 2006 and references therein), light absorption by aerosol particles is inversely correlated with $\lambda$, however the spectral dependence may vary in time. Absorbing organic carbon in particles from solid fuel sources have previously been seen to be considerably more important than organic carbon from vehicular sources and hence absorption may have a greater spectral dependence when this source type is dominant (e.g. Kirchstetter et al., 2004). Figure $7 \mathrm{~b}$ shows frequency distributions of $\stackrel{\circ}{a}_{\text {ap }}$ during periods when the environment is less influenced by solid fuel burning $(\mathrm{SFOA} / \mathrm{HOA}<2.5)$ and when solid fuel dominates over vehicular sources $(\mathrm{SFOA} / \mathrm{HOA}>2.5)$. During periods dominated by vehicular sources of OA, the median value of $\stackrel{\circ}{a p}_{\text {ap }}$ was 1.1 , whereas it increased considerably under the influence of solid fuel burning, peaking at between 1.4-1.5. 

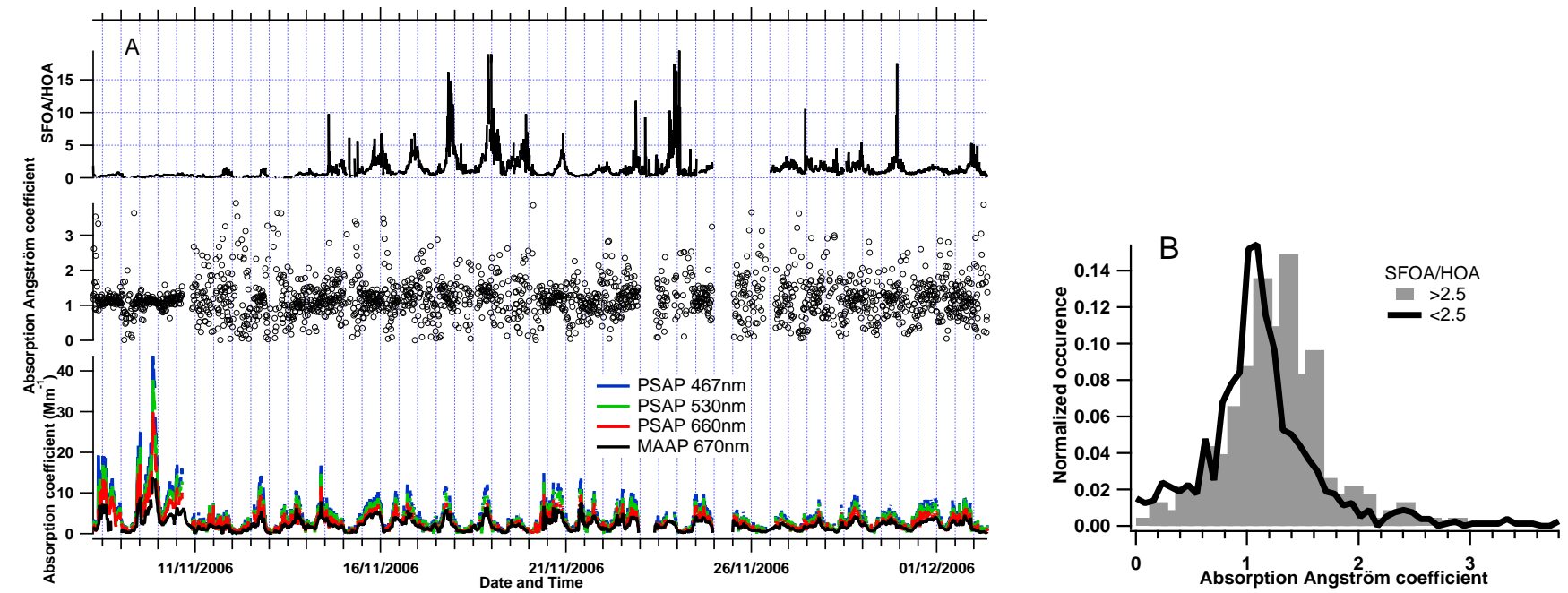

Fig. 7. (A) Time series of (from top to bottom): SFOA/HOA ratio; the absorption Ångström coefficient; the absorption coefficients measured at different $\lambda$ by the PSAP and MAAP instruments. (B) Frequency distributions of $\stackrel{\circ}{a}_{\text {ap }}$ for data during periods of increased solid fuel source influence $(\mathrm{SFOA} / \mathrm{HOA}>2.5)$, and enhanced influence from urban traffic emissions $(\mathrm{SFOA} / \mathrm{HOA}<0.25)$.

\section{Discussion}

\subsection{Physiochemical properties of aerosols and ageing}

The $\mathrm{BC}$ mixing efficiency, defined as the number fraction of thickly coated BC (Sect. 2.2), exhibited a minimum value of $0.18 \pm 0.05$ around 10:00. The dominance of thinly coated $\mathrm{BC}$ particles indicates little processing has occurred. The minimum in $\mathrm{BC}$ mixing efficiency coincides with the increase of $\mathrm{CN}$ and HOA concentration (Fig. 8) resulting from fresh urban sources. The BC mixing efficiency maintained an increasing trend throughout the average diurnal cycle, and reached a maximum $(0.31 \pm 0.08)$ at midnight when the surface temperature was low. The shallow nocturnal boundary layer may have decoupled the site from the contributing sources.

The OOA and HOA factors derived from the PMF analysis of the organic mass spectral data have been shown to be representative of secondary and primary organic aerosol respectively (Ulbrich et al., 2009), and the OOA fraction increases with distance from sources as particles become aged (Jimenez et al., 2009). The lowest OOA/POA ratio in this study coincided with the period of lowest BC mixing efficiency, and was significantly elevated from late afternoon. The OOA/POA at this site ranged from $0.5-1.7$, which is lower than the average value of OOA/POA for urban regions (1.7) reported by Zhang et al. (2007). This is not inconsistent, as Holme Moss is close to the main sources in Manchester and photochemical processing in wintertime is typically much slower than in summer when many of the studies used in the Zhang et al. (2007) study took place. Moreover, the OOA/HOA measured is higher than the value $(0.8)$ reported by Allan et al. (2010), who studied the environment close to the Manchester urban sources and was also conducted in the winter time, indicating some atmospheric processing of the organic aerosol occurred during transport. The OOA/POA is lower than OOA/HOA (1.1-3.5) as the SFOA also contributes some fraction of POA, but follows a similar trend to OOA/HOA. The OOA/POA is also higher than the value (0.4) observed in the Manchester urban study (Allan et al., 2010).

The organic mass $/ \mathrm{rBC}$ mass ratio $(\mathrm{OM} / \mathrm{rBC})$ was relatively stable at around $3.5 \pm 0.4$ through the daytime and evening, and then significantly increased to $5.6 \pm 0.6$ between $01: 00$ and 07:00 a.m. In past studies, the OC/EC (elemental carbon) ratio has been widely characterized based on the measurement from the field analyzer designed by Sunset Laboratory (Turpin et al., 1990). The OC/EC ratio has been long used as an indicator for the formation of secondary organics (e.g. Turpin and Huntzicker 1995). In this study, the analogous ratio of $\mathrm{OM} / \mathrm{rBC}$ is reported and higher $\mathrm{OM} / \mathrm{rBC}$ ratio during the night clearly demonstrates a strong degree of particle ageing.

The geometric mean mobility diameter $\left(D_{\mathrm{gm}}\right)$ calculated from DMPS measured size range $(25-740 \mathrm{~nm})$ showed lowest values around 10:00, and an increase at midnight (Fig. 8). The fresh urban sources contain a large fraction of smaller particles in the Aitken mode (Kittelson, 1998), and the size will increase as the particles become more aged.

In summary, the pollutants measured at the site from around 10:00 were characteristic of fresher sources. Between 10:00 and 13:00, the concentrations of pollutants increased significantly, and the high contribution to the OA from HOA identifies the main source to be urban outflow. The aerosols during this period were less atmospherically processed and included elevated amounts of fresh BC 

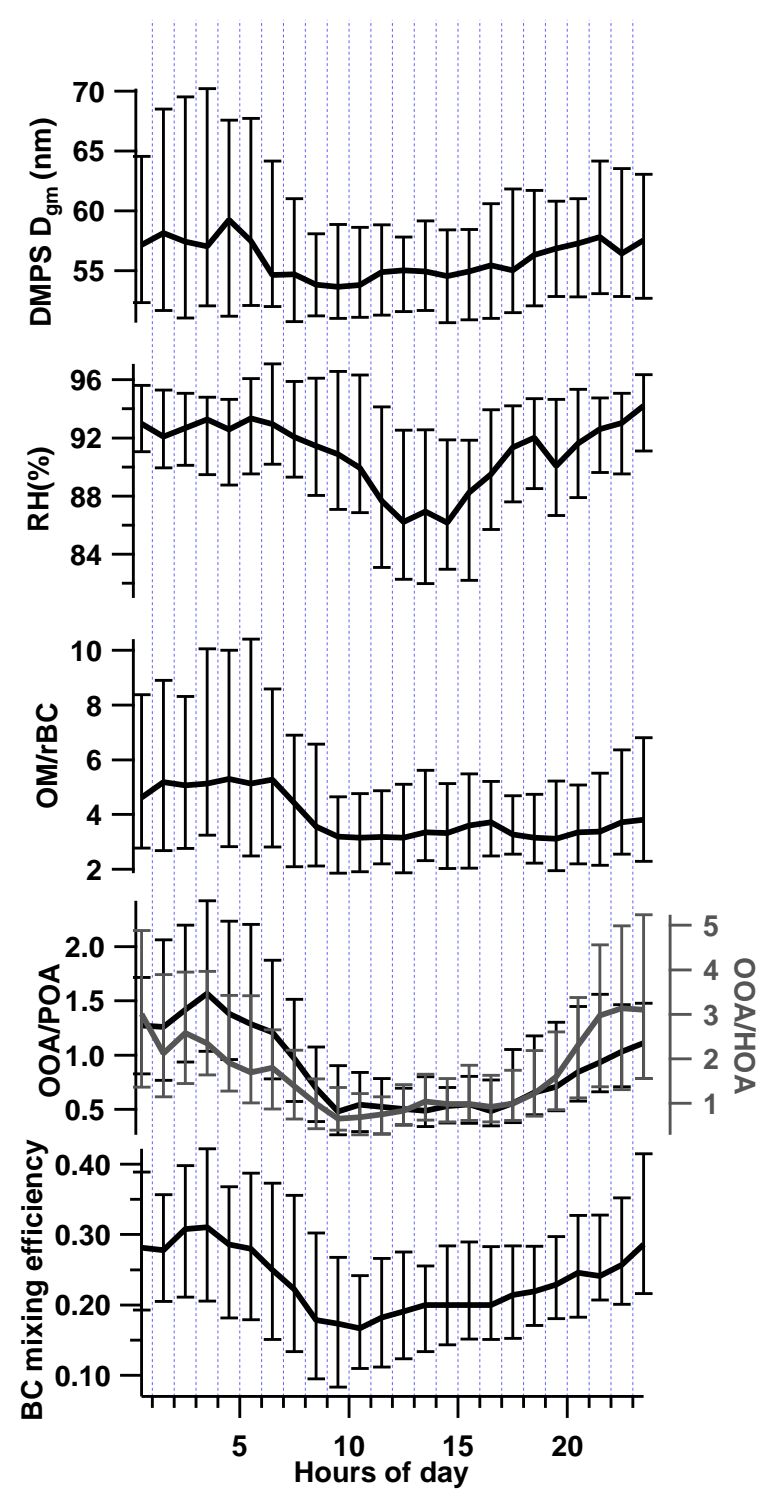

Fig. 8. From top to bottom, average diurnal variations of $\mathrm{rBC}$ core size, geometric mean diameter of DMPS, RH, OM/rBC, OOA/POA with OOA/HOA on the right axis and $\mathrm{BC}$ mixing efficiency. The lines show the median value associated with the error bars denoting $25 \%$ and $75 \%$ percentiles.

particles (i.e., low OM/rBC) (Fig. 8). In contrast, the aerosols sampled during the night contained less of a contribution from nearby sources, and the particles were more aged and atmospherically processed. This likely resulted from nocturnal decoupling of air in a shallow surface layer over the Manchester area preventing advection of pollution to the downwind hilltop site. The higher relative humidity during this period may have further enhanced the ageing processes (Fig. 8). The particles during this period were more typical of an aged regional background.
Unlike previous urban studies (Zhang et al., 2008; Allan et al., 2010), where primary organic aerosol particles are typically dominated by HOA and peak in the early morning and during the late afternoon, there was a substantial contribution from solid fuel burning throughout the evening period which led to enhanced loadings due to SFOA between 19:00 and midnight.

It is interesting to note that both $\mathrm{BC}$ mixing state and OOA/POA, which reflect the particle ageing process, continued to increase throughout the afternoon and evening despite additional significant fresh sources of solid fuel burning contributing in the late afternoon. Changes in the depth of the boundary layer, transport to the site and humidity during the day may all affect atmospheric processing times during the day and may contribute to the enhanced OOA/POA throughout the afternoon/evening period. However, the increased $\mathrm{BC}$ mixing efficiency and OOA/POA observed in the late afternoon may also partly result from different source specific characteristics. For example, Schwarz et al. (2008) reported that the BC mixing state was considerably higher for biomass burning than urban emissions. The organic aerosols emitted from wood burning have been shown to have a considerably high degree of oxygenation (Weimer et al., 2008; Dinar et al., 2006). The enhanced initial BC mixing state and OOA/POA from the source of solid fuel burning may partly explain the aerosol properties seen in the late afternoon.

We have shown that this site was influenced by multiple sources and we have investigated the extent to which the characteristics of primary aerosols from different sources can be individually identified. The emission factors of $1.61 \mu \mathrm{gHOA} / \mu \mathrm{gC}$ or $1.96 \mu \mathrm{gSFOA} / \mu \mathrm{gC}$ are deduced by a bilinear regression as discussed above. Lanz et al. (2007) reported a POA/BC of $1.1 \pm 0.1$ in summer at an urban background site in Zurich, Switzerland, where the POA was from a combination of sources including traffic, wood burning, charbroiling and a minor component derived from food cooking. A ratio of $\mathrm{HOA} / \mathrm{BC} 1.41 \pm 0.22$ was reported by Zhang et al. (2005) in Pittsburgh in the northeast of US The other reported values of POA/BC include a model based value of 1.4 (Yu et al., 2004) and a further study based on emission inventories that derived a value of 1.2 (Cabada et al., 2002). The source specific POA/BC emission factors are rarely reported in previous studies. The HOA/BC and SFOA/BC reported in this study are generally comparable to the previously reported POA/BC, but are slightly higher. This might be due to systematic differences in quantifying the $\mathrm{BC}$ mass, as most of the previous studies measured the $\mathrm{BC}$ mass using OC/EC method (Turpin et al., 1990) rather than quantifying the refractory $\mathrm{BC}$ mass as was done in this study. This study shows a higher OA/BC emission factor for solid fuel burning than urban emission, which is consistent with the results by Clarke et al. (2007), who studied freshly formed plumes from biomass burning and urban emission from an aircraft platform, observing a higher fraction of organic materials in the biomass burning plumes. 


\subsection{Aerosol optical properties}

\subsection{The spectral dependence of absorption and mass absorption coefficient}

The differences in the ratio of organic mass to $\mathrm{rBC}$ between the HOA and SFOA aerosols should have a significant effect on absorption. The $\stackrel{\circ}{a}_{\text {ap }}$ (Fig. 7b) has an average of 1.1 when POA was dominated by traffic emission $(\mathrm{SFOA} / \mathrm{HOA}<2.5)$. This value agrees with most of the previous studies (Bond and Bergstrom, 2006 and references therein) that a $\lambda^{-1}$ spectral dependence $\left(\stackrel{\circ}{a p}_{\mathrm{ap}}=1\right)$ is consistently observed when the pollutants originate primarily from high temperature combustion processes, such as diesel combustion in an urban environment. Under these conditions, the absorption is mainly contributed by the BC particles. When the POA was dominated by solid fuel burning $(\mathrm{SFOA} / \mathrm{HOA}>2.5), \stackrel{\circ}{a}_{\mathrm{ap}}$ increased to between 1.4 and 1.5, indicating a stronger spectral dependence. Brown carbon, produced at lower temperatures during the smoldering phase of combustion, common during biomass burning, was consistently observed to exhibit stronger spectral dependence with a slope of $\lambda^{-2}$ to $\lambda^{-6}\left(\stackrel{\circ}{a}_{\mathrm{ap}}=2-6\right)$ (Andreae and Gelenesér, 2006 and references therein). The stronger spectral dependence indicates the contribution of brown carbon on the absorbing properties of the aerosol when significantly influenced by solid fuel burning. However, $\stackrel{\circ}{a}_{\text {ap }}$ measured during this experiment was lower compared to other biomass burning studies. This may be due to the site being influenced by a combination of BC sources, but may also be a result of solid fuel burning being more efficient than biomass burning, leading to considerable uncertainties in attributing the absorption contribution by the species of brown carbon.

The stronger spectral dependence means the brown carbon will be more efficiently absorbing at shorter $\lambda$ compared to BC. Filter-based methods derive an absorption coefficient that is a combination of absorption from both brown carbon and $\mathrm{BC}$ but the absorption will be more significantly affected by the presence of brown carbon at shorter $\lambda$. A comparison of linear regressions of PSAP/MAAP-measured $\sigma_{\text {ap }}$ at different $\lambda$ with SP2-measured $\mathrm{rBC}$ mass is summarized in Table 2. The intercept is positive for all values of $\lambda$, suggesting a contribution to absorption by materials besides BC, most likely brown organic carbon. The intercept increases at shorter $\lambda$, as shown in Table 2, indicating an enhanced influence of brown carbon towards shorter $\lambda$. This suggests that the measured absorbing coefficient cannot be used to derive an equivalent $\mathrm{BC}$ mass at shorter wavelengths. However at longer $\lambda$, as the absorption of $\mathrm{BC}$ becomes dominant and the influence of brown carbon is less, more reliable estimates of the mass absorption cross section of black carbon are possible.

The slope of the linear regression can be interpreted as the absorption efficiency of $\mathrm{BC}$, the mass absorption cross section (MAC, Bond and Bergstrom, 2006). The MAC derived
Table 2. The linear regressions of absorption coefficient measured at different $\lambda$ with refractory $\mathrm{BC}$ mass, summarizing the slope, intercept and Pearson correlation coefficient.

\begin{tabular}{lcccc}
\hline $\begin{array}{l}\text { Linear regression } \\
\text { with rBC mass }\end{array}$ & $\begin{array}{c}\text { MAAP } \\
670 \mathrm{~nm}\end{array}$ & $\begin{array}{c}\text { PSAP } \\
660 \mathrm{~nm}\end{array}$ & $\begin{array}{c}\text { PSAP } \\
530 \mathrm{~nm}\end{array}$ & $\begin{array}{c}\text { PSAP } \\
467 \mathrm{~nm}\end{array}$ \\
\hline (MAC, $\left.\mathrm{m}^{2} \mathrm{~g}^{-1}\right)$ & $11.3 \pm 0.2$ & $18.5 \pm 0.3$ & $23.8 \pm 0.4$ & $28.0 \pm 0.4$ \\
Intercept & $0.74 \pm 0.03$ & $0.77 \pm 0.06$ & $0.88 \pm 0.07$ & $1.00 \pm 0.08$ \\
$r^{2}$ & 0.79 & 0.80 & 0.81 & 0.81 \\
\hline
\end{tabular}

from the MAAP measurement $(\lambda=670 \mathrm{~nm}, 11.3 \pm 0.2)$ is in agreement with an inter-laboratory study $\left(10.0 \mathrm{~m}^{2} \mathrm{~g}^{-1}\right)$ by Slowik et al. (2007), who studied flame generated soot particles using a similar instrument configuration, and also the $10.2 \pm 3.2(\lambda=630 \mathrm{~nm})$ reported from the free tropospheric site over Switzerland (Liu et al., 2010). The PSAP $(\lambda=660 \mathrm{~nm})$ measured about $40 \%$ higher than the MAAP at similar $\lambda$, resulting in a higher derived $\operatorname{MAC}(\lambda=660 \mathrm{~nm})$ than from MAAP. This discrepancy is different from earlier studies who conducted the comparison using urban air or kerosene soot in the laboratory (Müller et al., 2011). The PSAP/MAAP discrepancy may result from the systematic uncertainties from both instruments, such as the aerosol scattering interacting with the instrument fiber matrix. The MAAP simultaneously measures the transmittance and reflectance of the filter rather than the PSAP using external scattering measurement to correct absorption. Limited field measurements indicate that high concentrations of organic aerosols may cause a positive bias in the PSAP measurement up to $40-70 \%$ by interacting with the fiber filter matrix (Lack et al., 2008), which might contribute to the high MAC values from the current study; however, the response to organic liquids for the MAAP might need further investigations.

\subsubsection{The single scattering albedo}

The diurnal variation in the measured $\sigma_{\mathrm{ap}}$ showed no apparent $\lambda$ dependence as shown in Fig. 9. The $\sigma_{\text {ap }}$ initially peaked at around 11:00 and was elevated throughout the day, reaching a maximum at 18:00-19:00, and generally followed the diurnal trend of total $\mathrm{rBC}$ mass loading. The diurnal contributions of different species of aerosols to the total submicron aerosol mass are shown at the bottom panel of Fig. 9. The $\mathrm{rBC}$ mass fraction has the strongest linear correlation with $\sigma_{\mathrm{ap}}\left(r^{2}=0.30\right)$ compared to the other components of aerosol $\left(r^{2}<0.15\right)$ that could potentially contribute to $\sigma_{\mathrm{ap}}$, such as SFOA, HOA, OOA or total OM.

The single scattering albedo (SSA) is calculated at $\lambda=$ $700 \mathrm{~nm}$ by converting the measured $\sigma_{\mathrm{ap}, \mathrm{MAAP}} 670 \mathrm{~nm}$ to $\sigma_{\mathrm{ap}, 700 \mathrm{~nm}}$ based on a $\lambda^{-1}$ relationship (Bond et al., 1999) provided the influence of brown carbon at this wavelength range is minor. The SSA is calculated at the longer wavelength to minimize the influence from brown carbon, which 


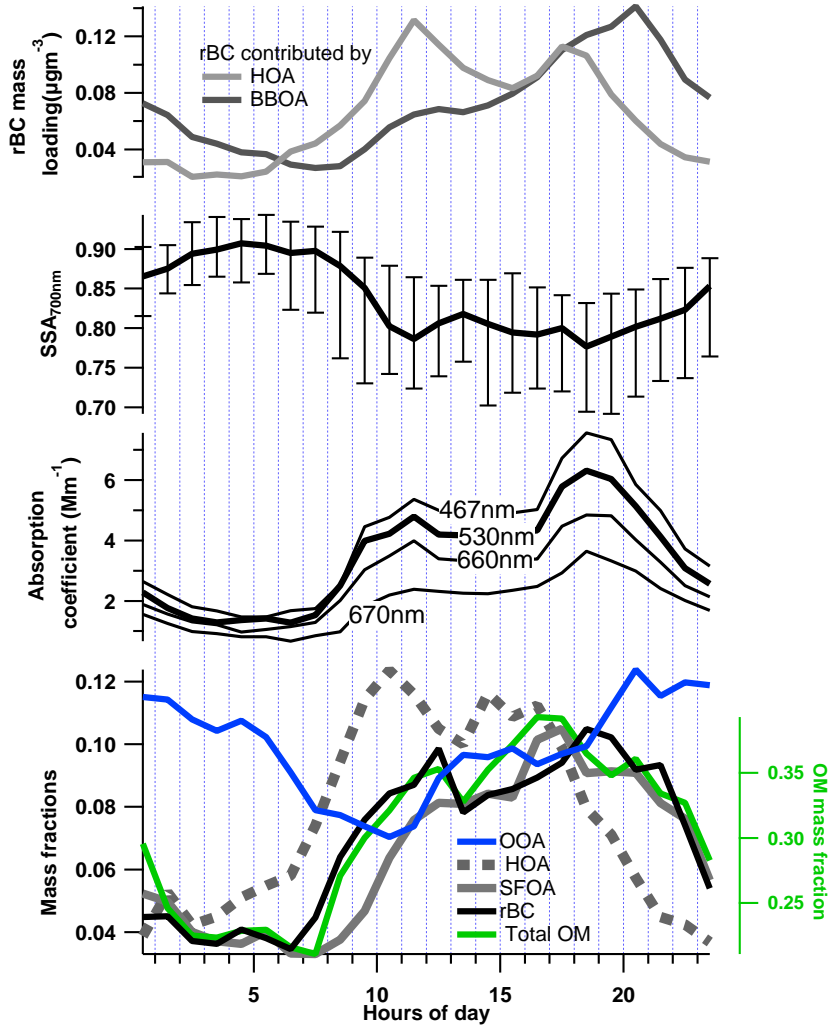

Fig. 9. Panels from top to bottom: rBC mass contributed by traffic and solid fuel burning; the single scattering albedo (SSA) at $\lambda=$ $700 \mathrm{~nm}$ derived from the nephelometer $(\lambda=700 \mathrm{~nm})$ and MAAP $(\lambda=670 \mathrm{~nm})$ measurements; the absorption coefficients at different $\lambda$; the diurnal variations in the mass fractions of OOA, HOA, SFOA, $\mathrm{rBC}$ and $\mathrm{OM}$ (on the right axis). The lines show the median value, and the error bars associated with $\mathrm{SSA}_{700 \mathrm{~nm}}$ denote the $25 \%$ and 75 percentiles.

is typically greater at shorter wavelengths. In Sect. 4.2.1 the MAC values calculated using the MAAP at $670 \mathrm{~nm}$ were more consistent with literature values than those of the PSAP at $660 \mathrm{~nm}$. Given this, we will present the SSA derived only from the MAAP measurements in this section. It is shown that the diurnal cycle of SSA is significantly modulated by $\sigma_{\text {ap }}-$ the two lowest values of SSA $700 \mathrm{~nm}(0.79 \pm 0.06$ and $0.75 \pm 0.05)$ correspond to the first and second maxima in $\sigma_{\text {ap. }}$ The BC mass fraction is anti-correlated with the SSA as expected, given that $\sigma_{\text {ap }}$ is mainly modulated by the BC mass fraction. The derived contributions to $\mathrm{rBC}$ from SFOA and HOA sources are shown in the top panel of Fig. 9. The morning minimum in SSA was predominately a result of BC from urban emission whereas the late afternoon minimum SSA was derived from a combination of traffic and solid fuel burning. The SSA reached a maximum during the night, when aged particles were dominant and the $\mathrm{rBC}$ mass fraction was low.
A modelling study by Tsyro et al. (2007) reported a varied EC mass fraction of $3-15 \%$ in $\mathrm{PM}_{2.5}$ across Europe using the 2002-2004 emission inventory, and simulated higher mass fraction in the populated residential or commercial regions, which agrees well with the observations in this study. Although both the $\mathrm{BC}$ mass and $\sigma_{\mathrm{ap}}$ at this site are lower by a factor of about 5 compared to the urban study conducted in Mexico City (Baumgardner et al., 2007), the BC mass fraction of between 0.03 and 0.16 reported in this study is consistent with that measured in Mexico City (0.03-0.25). Furthermore, the range of SSA reported in this study (0.74-0.98) also falls within a similar range to that reported by Baumgardner et al. (2007) (0.72-0.91). This suggests the SSA is significantly modulated by the $\mathrm{BC}$ mass fraction rather than the absolute loadings of BC.

Figure 10a shows the relationship between the $\mathrm{SSA}_{700 \mathrm{~nm}}$ and $\mathrm{rBC}$ mass fraction for the whole data set. SSA is anticorrelated with $\mathrm{rBC}$ mass fraction. There is also evidence that SSA is associated with $\mathrm{BC}$ mixing state. It is shown that the majority of the $\mathrm{BC}$ particles with mixing efficiency $>0.28$ (the red dots) have an $\mathrm{rBC}$ mass fraction of $<0.05$, and an $\mathrm{SSA}_{700 \mathrm{~nm}}$ of $>0.78$ (Fig. 10b). These particles were mainly observed during the night, when the contribution from fresh emissions was at its minimum and the aerosol population was dominated by the regional background. The variation of SSA from $0.78-0.99$ during this time shows little dependence on the rBC mass fraction.

Figure 10a also shows that the lower values of $\mathrm{SSA}_{700 \mathrm{~nm}}$ $(<0.76)$ are associated with the particles with $\mathrm{BC}$ mass fraction $>0.05$ and lower BC mixing efficiency $(<0.22)$. These particles were largely influenced by fresh sources from both traffic emission and solid fuel burning. However, a fraction of BC particles with lower mixing efficiency had a higher SSA, leading to a wide range of SSAs for a given BC mixing efficiency (Fig. 10b). These particles may have experienced cloud/precipitation scavenging processes during which BC particles with substantial coatings were preferably wet removed. When the BC mixing efficiency $<0.22$, the SSA is very dependent on the $\mathrm{BC}$ mass fraction, suggesting the importance of $\mathrm{BC}$ incorporation/removal on modulating the $\mathrm{SSA}_{700 \mathrm{~nm}}$.

\section{Summary}

This study characterizes sub-micron, carbonaceous aerosols at a hill top site, Holme Moss, immediately downwind of a major conurbation in the UK during the wintertime of 2006 using a series of in-situ measurements. Non-refractory aerosol component mass was measured using an Aerodyne Aerosol Mass Spectrometer. Refractory black carbon (rBC) mass was measured using a Single Particle Soot Photometer (SP2) which was also able to characterize the extent to which black carbon particles were mixed with coated 

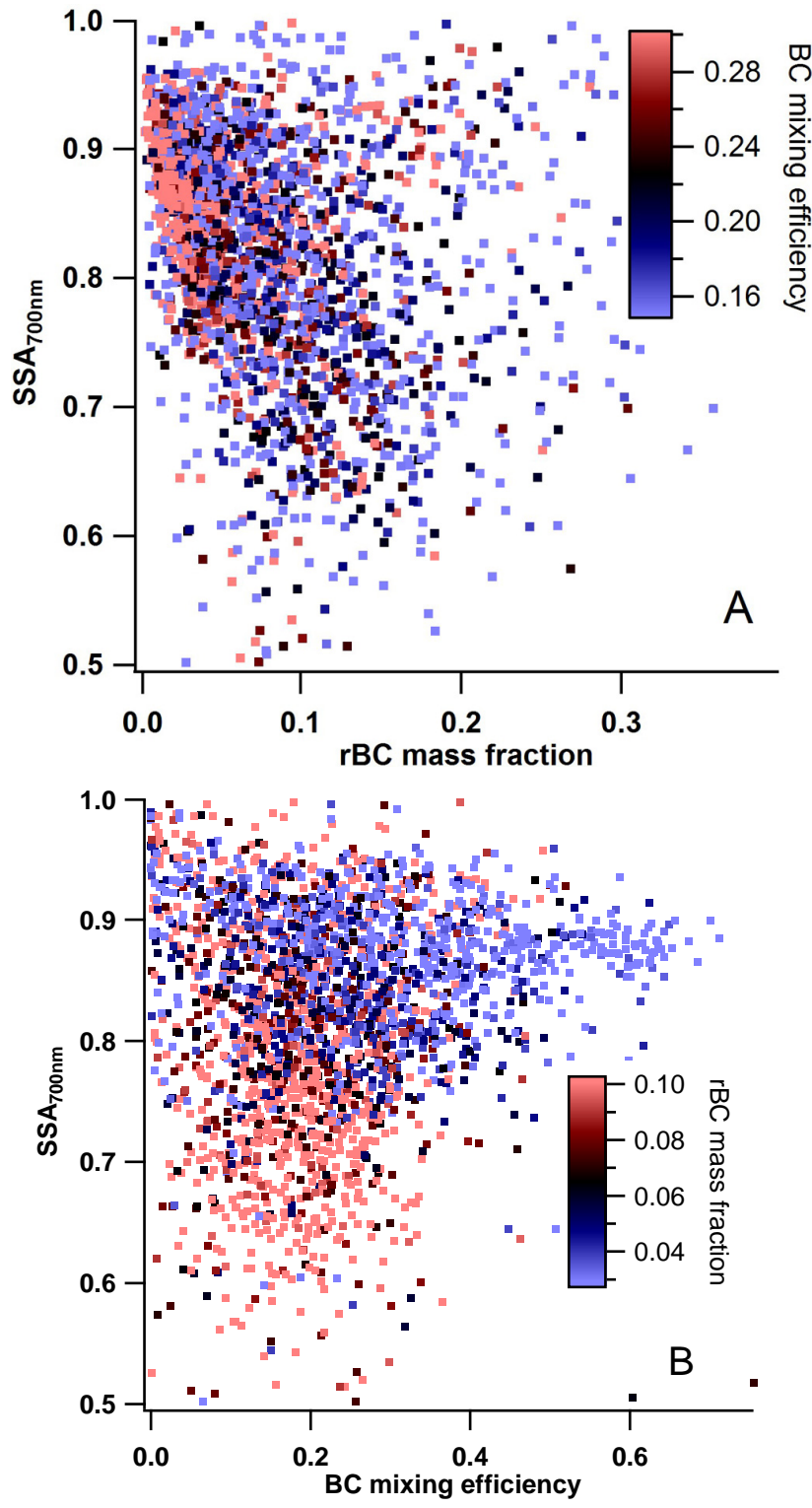

Fig. 10. (A) $\mathrm{SSA}_{700 \mathrm{~nm}}$ correlated with $\mathrm{rBC}$ mass fraction coloured with BC mixing efficiency; (B) SSA700 nm correlated with BC mixing efficiency coloured with $\mathrm{rBC}$ mass fraction.

material. These data were used to probe the impact variations in sources had on the optical properties of the aerosol.

Positive matrix factorization was applied to the time series of the particle organic mass spectra measured by the AMS. This demonstrated that besides the organic aerosol that was secondary in nature (oxygenated organic aerosol, OOA), there was a significant contribution of primary organic aerosols (POA). PMF identified two factors which were interpreted to be primary: traffic combustion related aerosols (hydrocarbon-like organic aerosol, HOA) and the solid fuel burning particles (solid fuel organic aerosol, SFOA), the latter resulting from residential space heating. The diurnal variability of the aerosol components and derived factors indicated this site began to be influenced by fresh urban outflow from the upwind city of Manchester in the late morning and the more localized sources of solid fuel burning became significant from late afternoon through the early part of the night.

The concentrations of $\mathrm{rBC}$ aerosols were associated with the emission of POA from both sources, showing two peaks in the diurnal cycle of $150 \pm 30 \mathrm{ng} \mathrm{m}^{-3}$ in the late morning and $270 \pm 50 \mathrm{ng} \mathrm{m}^{-3}$ in the late afternoon. Schaap et al. (2004) modeled rBC concentrations and showed BC concentrations ranged from $50 \mathrm{ng} \mathrm{m}^{-3}$ in remote regions to more than $1000 \mathrm{ng} \mathrm{m}^{-3}$ over densely populated urban areas over Europe, consistent with our data. A bilinear fit of the HOA and SFOA to the rBC time series was used to attribute the contribution of the different sources to the total rBC. Emission factors of $1.61 \mu \mathrm{gHOA} / \mu \mathrm{gC}$ and $1.96 \mu \mathrm{gSFOA} / \mu \mathrm{gC}$ were derived for traffic emission and solid fuel burning respectively. Similar differences in the absorbing properties were also observed during periods when one or the other source dominated. The peak in the absorbing Ångström coefficient was higher (1.4-1.5) when solid fuel sources dominated the primary aerosol compared to traffic-related sources (1.1). This is consistent with previous studies showing that biomass burning emissions frequently contain a substantial amount of brown carbon particles that absorb the light more efficiently at shorter wavelength (Andreae and Gelenesér 2006, and references therein). This highlights the importance of incorporating the measurement of absorbing organic carbon into the global models, as suggested by Koch et al. (2009).

The rBC mass contributed $3-16 \%$ of the total measured submicron aerosol mass in this study. The SSA at $\lambda=$ $700 \mathrm{~nm}$ was shown to be significantly influenced by and anticorrelated to the mass fraction of rBC. Given the highest contributions to the $\mathrm{BC}$ in Europe are from motor vehicles and residential combustion of solid fuels (Schaap et al., 2004; Kupiainen and Klimont, 2007), the emissions from these sources are likely to provide the largest uncertainty in the European BC budget (Tsyro et al., 2007). It is therefore important to provide information on the spatial and temporal variations of $\mathrm{BC}$ from both transport and residential combustion sources to constrain models and evaluate regional radiation budgets.

Periods when the fraction of $\mathrm{rBC}$ with significant coating was enhanced were observed to be largely associated with periods of higher SSA, and most of these particles were observed at night and resulted from the regional background and were aged. The fraction of $\mathrm{rBC}$ particles with thick coatings decreased significantly during periods dominated by fresh sources, when the SSA was only weakly dependent on the $\mathrm{rBC}$ mixing efficiency but showed a strong dependence on the $\mathrm{BC}$ mass fraction. Changes in the $\mathrm{BC}$ wet scavenging rate have a noticeable effect on the modeled concentration (Vignati et al., 2010) over Europe, leading to an uncertainty of $5-25 \%$ on concentrations for most of the regions and $30-40 \%$ in remote areas (Tsyro et al., 2007). However, 
the dependence of the atmospheric removal of $\mathrm{BC}$ on its mixing state is at present insufficiently understood (Koch et al., 2009). Measurements of BC mixing state such as those conducted in this work may provide insights into $\mathrm{BC}$ removal processes associated with the radiative forcing effects in the future.

\section{Supplementary material related to this article is available online at: http://www.atmos-chem-phys.net/11/1603/2011/ acp-11-1603-2011-supplement.pdf.}

Acknowledgements. The work was supported by the Natural Environment Research Council ADIENT project NE/E011101/1. The NERC National Centre for Atmospheric Science (NCAS) Facility for Ground Atmospheric Measurements (FGAM) supported some of the instrumentation. Funding for E. Andrews and J. Ogren to participate in this project was supplied by DOE's ASP program under grant\# DE-A102-05ER63996. DOE's Pacific Northwest National Laboratory, under the auspices of the ASP program, also loaned some of the instruments used during the project.

Edited by: A. Petzold

\section{References}

Alfarra, M. R., Prevot, A. S. H., Szidat, S., Sandradewi, J., Weimer, S., Lanz, V. A., Schreiber, D., Mohr, M., and Baltensperger, U.: Identification of the mass spectral signature of organic aerosols from wood burning emissions, Environ. Sci. Technol., 41, 57705777, doi:10.1021/Es062289b, 2007.

Allan, J. D., Alfarra, M. R., Bower, K. N., Williams, P. I., Gallagher, M. W., Jimenez, J. L., McDonald, A. G., Nemitz, E., Canagaratna, M. R., Jayne, J. T., Coe, H., and Worsnop, D. R.: Quantitative sampling using an aerodyne aerosol mass spectrometer -2 . Measurements of fine particulate chemical composition in two UK Cities, J. Geophys. Res.-Atmos., 108, 4091, doi:10.1029/2002JD002359, 2003.

Allan, J. D., Coe, H., Bower, K. N., Alfarra, M. R., Delia, A. E., Jimenez, J. L., Middlebrook, A. M., Drewnick, F., Onasch, T. B., Canagaratna, M. R., Jayne, J. T., and Worsnop, D. R.: A generalised method for the extraction of chemically resolved mass spectra from aerodyne aerosol mass spectrometer data, J. Aerosol. Sci., 35, 909-922, 2004.

Allan, J. D., Williams, P. I., Morgan, W. T., Martin, C. L., Flynn, M. J., Lee, J., Nemitz, E., Phillips, G. J., Gallagher, M. W., and Coe, H.: Contributions from transport, solid fuel burning and cooking to primary organic aerosols in two UK cities, Atmos. Chem. Phys., 10, 647-668, doi:10.5194/acp-10-647-2010, 2010.

Anderson, T. L., Covert, D. S., Marshall, S. F., Laucks, M. L., Charlson, R. J., Waggoner, A. P., Ogren, J. A., Caldow, R., Holm, R. L., Quant, F. R., Sem, G. J., Wiedensohler, A., Ahlquist, N. A., Bates, T. S.: Performance Characteristics of a High-Sensitivity, Three-Wavelength, Total Scatter/Backscatter Nephelometer. J. Atmos. Oceanic Technol., 13, 967-986, 1996.

Andreae, M. O. and Gelencsér, A.: Black carbon or brown carbon? The nature of light-absorbing carbonaceous aerosols, At- mos. Chem. Phys., 6, 3131-3148, doi:10.5194/acp-6-3131-2006, 2006.

Baumgardner, D., Kok, G., and Raga, G.: Warming of the Arctic lower stratosphere by light absorbing particles, Geophys. Res. Lett., 31, L06117, doi:10.1029/2003GL018883, 2004.

Baumgardner, D., Kok, G. L., and Raga, G. B.: On the diurnal variability of particle properties related to light absorbing carbon in Mexico City, Atmos. Chem. Phys., 7, 2517-2526, doi:10.5194/acp-7-2517-2007, 2007.

Beswick, K. M., Choularton, T. W., Inglis, D. W. F., Dore, A. J., and Fowler, D.: Influences on long-term trends in ion concentration and deposition at Holme Moss, Atmos. Environ., 37, 1927-1940, 2003.

Bond, T. C.: Spectral dependence of visible light absorption by carbonaceous particles emitted from coal combustion, Geophys. Res. Lett., 28, 4075-4078, 2001.

Bond, T. C., Anderson, T. L., and Campbell, D.: Calibration and intercomparison of filter-based measurements of visible light absorption by aerosols, Aerosol Sci. Tech., 30, 582-600, 1999.

Cabada, J. C., Pandis, S. N., and Robinson, A. L.: Sources of atmospheric carbonaceous particulate matter in Pittsburgh, Pennsylvania, J. Air Waste Manag. Assoc., 52(6), 732-741, 2002.

Canagaratna, M. R., Jayne, J. T., Jimenez, J. L., Allan, J. D., Alfarra, M. R., Zhang, Q., Onasch, T. B., Drewnick, F., Coe, H., Middlebrook, A., Delia, A., Williams, L. R., Trimborn, A. M., Northway, M. J., DeCarlo, P. F., Kolb, C. E., Davidovits, P., and Worsnop, D. R.: Chemical and microphysical characterization of ambient aerosols with the aerodyne aerosol mass spectrometer, Mass Spectrom. Rev., 26, 185-222, 2007.

Capes, G., Johnson, B., McFiggans, G., Williams, P. I., Haywood, J., and Coe, H.: Aging of biomass burning aerosols over west Africa: Aircraft measurements of chemical composition, microphysical properties, and emission ratios, J. Geophys. Res.Atmos., 113, D00C15, doi:10.1029/2008jd009845, 2008.

Chu, S.: Stable estimate of primary OC/EC ratios in the EC tracer method, Atmos. Environ., 39, 8, 1383-1392, 2005.

Clarke, A., McNaughton, C., Kapustin, V., Shinozuka, Y., Howell, S., Dibb, J., Zhou J., Anderson, B., Brekhovskikh, V., Turner, H., Pinkerton, M.: Biomass burning and pollution aerosol over North America: Organic components and their influence on spectral optical properties and humidification response, J. Geophys. Res., 112, D12S18, doi:10.1029/2006JD007777, 2007.

Cross, E. S., Slowik, J., Davidovits, P., Allan, J., Worsnop, D., Jayne, J., Lewis, D., Canagaratna, M., and Onasch, T.: Laboratory and ambient particle density determinations using light scattering in conjunction with aerosol mass spectrometry, Aerosol Sci. Tech., 41(4), 343-359, 2007.

Dinar, E., Mentel, T. F., and Rudich, Y.: The density of humic acids and humic like substances (HULIS) from fresh and aged wood burning and pollution aerosol particles, Atmos. Chem. Phys., 6, 5213-5224, doi:10.5194/acp-6-5213-2006, 2006.

Drewnick, F., Hings, S., DeCarlo, P., Jayne, J. T., Gonin, M., Fuhrer, K., Weimer, S., Jimenez, J. L., Demerjian, K. L., Borrmann, S., and Worsnop, D. R.: A New Time-of-Flight Aerosol Mass Spectrometer (TOF-AMS) - Instrument Description and First Field Deployment, Aerosol Sci. Tech., 39, 7, 637-658, 2005.

Huffman, J. A., Docherty, K. S., Mohr, C., Cubison, M. J., Ulbrich, I. M., Ziemann, P. J., Onasch, T. B., and Jimenez, J. L.: Chemically-resolved volatility measurements of organic aerosol 
from different sources, Environ. Sci. Technol., 43, 5351-5357, doi:10.1021/es803539d, 2009.

Jimenez, J. L., Canagaratna, M. R., Donahue, N. M., Prevot, A. S. H., Zhang, Q., Kroll, J. H., DeCarlo, P. F., Allan, J. D., Coe, H., Ng, N. L., Aiken, A. C., Docherty, K. S., Ulbrich, I. M., Grieshop, A. P., Robinson, A. L., Duplissy, J., Smith, J. D., Wilson, K. R., Lanz, V. A., Hueglin, C., Sun, Y. L., Tian, J., Laaksonen, A., Raatikainen, T., Rautiainen, J., Vaattovaara, P., Ehn, M., Kulmala, M., Tomlinson, J. M., Collins, D. R., Cubison, M. J., E., Dunlea, J., Huffman, J. A., Onasch, T. B., Alfarra, M. R., Williams, P. I., Bower, K., Kondo, Y., Schneider, J., Drewnick, F., Borrmann, S., Weimer, S., Demerjian, K., Salcedo, D., Cottrell, L., Griffin, R., Takami, A., Miyoshi, T., Hatakeyama, S., Shimono, A., Sun, J. Y., Zhang, Y. M., Dzepina, K., Kimmel, J. R., Sueper, D., Jayne, J. T., Herndon, S. C., Trimborn, A. M., Williams, L. R., Wood, E. C., Middlebrook, A. M., Kolb, C. E., Baltensperger, U., and Worsnop, D. R.: Evolution of Organic Aerosols in the Atmosphere, Science, 326, 1525-1529, doi:10.1126/science.1180353, 2009.

Jordan, T. B., Seen, A. J., and Jacobsen, G. E.: Levoglucosan as an atmospheric tracer for wood smoke, Atmos. Environ., 40, 53165321, doi:10.1016/j.atmosenv.2006.03.023, 2006.

Kirchstetter, T. W., Novakov, T., and Hobbs, P. V.: Evidence that the spectral dependence of light absorption by aerosols is affected by organic carbon, J. Geophys. Res., 109, D21208, doi:10.1029/2004JD004999, 2004.

Kittelson, D. B.: Engines and nanoparticles: A review, J. Aerosol Sci., 29, 575-588, 1998.

Koch, D., Schulz, M., Kinne, S., McNaughton, C., Spackman, J. R., Balkanski, Y., Bauer, S., Berntsen, T., Bond, T. C., Boucher, O., Chin, M., Clarke, A., De Luca, N., Dentener, F., Diehl, T., Dubovik, O., Easter, R., Fahey, D. W., Feichter, J., Fillmore, D., Freitag, S., Ghan, S., Ginoux, P., Gong, S., Horowitz, L., Iversen, T., Kirkevåg, A., Klimont, Z., Kondo, Y., Krol, M., Liu, X., Miller, R., Montanaro, V., Moteki, N., Myhre, G., Penner, J. E., Perlwitz, J., Pitari, G., Reddy, S., Sahu, L., Sakamoto, H., Schuster, G., Schwarz, J. P., Seland, Ø., Stier, P., Takegawa, N., Takemura, T., Textor, C., van Aardenne, J. A., and Zhao, Y.: Evaluation of black carbon estimations in global aerosol models, Atmos. Chem. Phys., 9, 9001-9026, doi:10.5194/acp-9-9001-2009, 2009.

Kondo, Y., Komazaki, Y., Miyazaki, Y., Moteki, N., Takegawa, N., Kodama, D., Deguchi, S., Nogami, M., Fukuda, M., Miyakawa, T., Morino, Y., Koike, M., Sakurai, H., and Ehara, K.: Temporal variations of elemental carbon in Tokyo, J. Geophys. Res., 111, D12205, doi:10.1029/2005JD006257, 2006.

Kupiainen, K. and Klimont, Z.: Primary emissions of fine carbonaceous particles in Europe, Atmos. Environ., 41, 2156-2170, 2007.

Lack, D. A., Cappa, C. D., Covert, D. S., Baynard, T., Massoli, P., Sierau, B., Bates, T. S., Quinn, P. K., Lovejoy, E. R., and Ravishankara, A. R.: Bias in filter-based aerosol light absorption measurements due to organic aerosol loading: Evidence from ambient measurements, Aerosol Sci. Technol., 42, 1033-1041, doi:f10.1080/02786820802389277, 2008.

Lanz, V. A., Alfarra, M. R., Baltensperger, U., Buchmann, B., Hueglin, C., and Prévôt, A. S. H.: Source apportionment of submicron organic aerosols at an urban site by factor analytical modelling of aerosol mass spectra, Atmos. Chem. Phys., 7,
1503-1522, doi:10.5194/acp-7-1503-2007, 2007.

Liu, D., Flynn, M., Gysel, M., Targino, A., Crawford, I., Bower, K., Choularton, T., Jurányi, Z., Steinbacher, M., Hüglin, C., Curtius, J., Kampus, M., Petzold, A., Weingartner, E., Baltensperger, U., and Coe, H.: Single particle characterization of black carbon aerosols at a tropospheric alpine site in Switzerland, Atmos. Chem. Phys., 10, 7389-7407, doi:10.5194/acp-10-7389-2010, 2010.

McFiggans, G., Alfarra, M. R., Allan, J., Bower, K., Coe, H., Cubison, M., Topping, D., Williams, P., Decesari, S., Facchini, C., and Fuzzi, S.: Simplification of the representation of the organic component of atmospheric particulates, Faraday Discuss., 130, 341-362, 2005.

Morgan, W. T., Allan, J. D., Bower, K. N., Esselborn, M., Harris, B., Henzing, J. S., Highwood, E. J., Kiendler-Scharr, A., McMeeking, G. R., Mensah, A. A., Northway, M. J., Osborne, S., Williams, P. I., Krejci, R., and Coe, H.: Enhancement of the aerosol direct radiative effect by semi-volatile aerosol components: airborne measurements in North-Western Europe, Atmos. Chem. Phys., 10, 8151-8171, doi:10.5194/acp-10-8151-2010, 2010.

Morino, Y., Kondo, Y., Takegawa, N., Miyazaki, Y., Kita, K., Komazaki, Y., Fukuda, M., Miyakawa, T., Moteki, N., and Worsnop, D. R.: Partitioning of $\mathrm{HNO}_{3}$ and particulate nitrate over tokyo: Effect of vertical mixing, J. Geophys. Res.-Atmos., 111, D15215, doi:10.1029/2005jd006887, 2006.

Müller, T., Henzing, J. S., de Leeuw, G., Wiedensohler, A., Alastuey, A., Angelov, H., Bizjak, M., Collaud Coen, M., Engström, J. E., Gruening, C., Hillamo, R., Hoffer, A., Imre, K., Ivanow, P., Jennings, G., Sun, J. Y., Kalivitis, N., Karlsson, H., Komppula, M., Laj, P., Li, S.-M., Lunder, C., Marinoni, A., Martins dos Santos, S., Moerman, M., Nowak, A., Ogren, J. A., Petzold, A., Pichon, J. M., Rodriquez, S., Sharma, S., Sheridan, P. J., Teinilä, K., Tuch, T., Viana, M., Virkkula, A., Weingartner, E., Wilhelm, R., and Wang, Y. Q.: Characterization and intercomparison of aerosol absorption photometers: result of two intercomparison workshops, Atmos. Meas. Tech., 4, 245-268, doi:10.5194/amt-4-245-2011, 2011.

National atmospheric emissions inventory (NAEI): available at: http://www.naei.org.uk, last access: 4 August 2009.

Ng, N. L., Canagaratna, M. R., Zhang, Q., Jimenez, J. L., Tian, J., Ulbrich, I. M., Kroll, J. H., Docherty, K. S., Chhabra, P. S., Bahreini, R., Murphy, S. M., Seinfeld, J. H., Hildebrandt, L., Donahue, N. M., DeCarlo, P. F., Lanz, V. A., Prévôt, A. S. H., Dinar, E., Rudich, Y., and Worsnop, D. R.: Organic aerosol components observed in Northern Hemispheric datasets from Aerosol Mass Spectrometry, Atmos. Chem. Phys., 10, 46254641, doi:10.5194/acp-10-4625-2010, 2010.

Paatero, P.: Least squares formulation of robust non-negative factor analysis, Chemometr. Intell. Lab., 37, 23-35, 1997.

Petzold, A. and Schönlinner, M.: Multi-angle absorption photometry - a new method for the measurement of aerosol light absorption and atmospheric black carbon, J. Aerosol Sci., 35, 421-441, 2004.

Ramanathan, V. and Carmichael, G.: Global and regional climate changes due to black carbon, Nature Geosci., 1, 221-227, doi:10.1038/ngeo156, 2008.

Robinson, A. L., Donahue, N. M., Shrivastava, M. K., Weitkamp, E. A., Sage, A. M., Grieshop, A. P., Lane, T. E., Pierce, J. R., and 
Pandis, S. N.: Rethinking organic aerosols: Semivolatile emissions and photochemical aging, Science, 315, 1259-1262, 2007.

Rogge, W. F., Hildemann, L. M., Mazurek, M. A., Cass, G. R., and Simoneit, B. R. T.: Sources of fine organic aerosol, Environ. Sci. Technol., 27(4), 636-651, doi:10.1021/es00041a007, 1993.

Schaap, M., Van Der Gon, H. A. C. D., Dentener, F. J., Visschedijk, A. J. H., Van Loon, M., ten Brink, H. M., Putaud, J.-P., Guillaume, B., Liousse, C., and Builtjes, P. J. H.: Anthropogenic black carbon and fine aerosol distribution over Europe, J. Geophys. Res., 109, D18207, doi:10.1029/2003JD004330, 2004.

Schneider, J., Hock, N., Weimer, S., and Borrmann, S.: Nucleation particles in diesel exhaust: Composition inferred from in situ mass spectrometric analysis, Environ. Sci. Technol., 39, 61536161, 2005.

Schneider, J., Weimer, S., Drewnick, F., Borrmann, S., Helas, G., Gwaze, P., Schmid, O., Andreae, M. O., and Kirchner, U.: Mass spectrometric analysis and aerodynamic properties of various types of combustion-related aerosol particles, Int. J. Mass Spectrom., 258, 37-49, doi:10.1016/j.ijms.2006.07.008, 2006.

Schwarz, J. P., Gao, R. S., Fahey, D. W., Thomson, D. S., Watts, L. A., Wilson, J. C., Reeves, J. M., Baumgardner, D. G., Kok, G. L., Chung, Schulz, S. M., Hendricks, J., Lauer, A., Kärcher, B., Slowik, J. G., Rosenlof, K. H., Thompson, T. L., Langford, A. O., Lowenstein, M., and Aikin, K. C.: Single-particle measurements of midlatitude black carbon and light-scattering aerosols from the boundary layer to the lower stratosphere, J. Geophys. Res., 111, D16207, doi:10.1029/2006JD007076, 2006.

Schwarz, J. P., Gao, R. S., Spackman, J. R., Watts, L. A., Thomson, D. S., Fahey, D. W., Ryerson, T. B., Peischl, J., Holloway, J. S., Trainer, M., Frost, G. J., Baynard, T., Lack, D. A., de Gouw, J. A., Warneke, C., and Del Negro, L. A.: Measurement of the mixing state, mass, and optical size of individual black carbon particles in urban and biomass burning emissions, Geophys. Res. Lett., 35, L13810, doi:10.1029/2008GL033968, 2008.

Sheridan, P. J., Delene, D. J., and Ogren, J. A.: Four years of continuous surface aerosol measurements from the Department of Energy's Atmospheric Radiation Measurement Program Southern Great Plains Cloud and Radiation Testbed site, J. Geophys. Res., 106, 20735-20747, doi:10.1029/2001JD000785, 2001.

Simoneit, B. R. T.: Biomass burning - a review of organic tracers for smoke from incomplete combustion, Appl. Geochem., 17, 129-162, 2002.

Slowik, J. G., Cross, E., Han, J., Davidovits, P., Onasch, T. B., Jayne, J. T., Williams, L. R., Canagaratna, M. R., Worsnop, D. R., Chakrabarty, R. K., Arnott, W. P., Schwarz, J. P., Gao, R. S., Fahey, D. W., and Kok, G. L.: An intercomparison of instruments measuring black carbon content of soot particles, Aerosol Sci. Technol., 41, 295-314, doi:10.1080/02786820701197078, 2007.

Smoke control areas: http://www.uksmokecontrolareas.co.uk, last access: 6 April 2009.

Stephens, M., Turner, N., and Sandberg, J.: Particle identification by laser-induced incandescence in a solidstate laser cavity, Appl. Optics, 42, 3726-3736, 2003.
Tsyro, S., Simpson, D., Tarrason, L., Klimont, Z., Kupiainen, K., Pio, C., and Yttri, K. E.: Modeling of elemental carbon over Europe, J. Geophys. Res.-Atmos., 112, D23S19, doi:10.1029/2006JD008164, 2007.

Turpin, B. J. and Huntzicker, J. J.: Identification of Secondary Organic Aerosol Episodes and Quantitation of Primary and Secondary Organic Aerosol Concentrations during Scaqs, Atmos. Environ., 29, 3527-3544, 1995.

Turpin, B. J., Cary, R. A., and Huntzicker, J. J.: An in situ, time-resolved analyzer for aerosol organic and elemental carbon, Aerosol Sci. Technol., 12(1), 161-171, 1990.

Ulbrich, I. M., Canagaratna, M. R., Zhang, Q., Worsnop, D. R., and Jimenez, J. L.: Interpretation of organic components from Positive Matrix Factorization of aerosol mass spectrometric data, Atmos. Chem. Phys., 9, 2891-2918, doi:10.5194/acp-9-2891-2009, 2009.

Vignati, E., Karl, M., Krol, M., Wilson, J., Stier, P., and Cavalli, F.: Sources of uncertainties in modelling black carbon at the global scale, Atmos. Chem. Phys., 10, 2595-2611, doi:10.5194/acp-102595-2010, 2010.

Weimer, S., Alfarra, M. R., Schreiber, D., Mohr, M., Prevot, A. S. H., and Baltensperger, U.: Organic aerosol mass spectral signatures from wood-burning emissions: Influence of burning conditions and wood type, J. Geophys. Res.-Atmos., 113, D10304, doi:10.1029/2007jd009309, 2008.

Williams, P. I.: Construction and Validation of a DMPS for Aerosol Characterization, PhD thesis, Department of Physics, Manchester, UK, UMIST, 1999.

Yu, S., Dennis, R. L., Bhave, P. V., and Eder, B. K.: Primary and secondary organic aerosols over the United States: estimates on the basis of observed organic carbon (OC) and elemental carbon (EC), and air quality modeled primary OC/EC ratios, Atmos. Environ., 38(31), 5257-5268, 2004.

Zhang, Q., Worsnop, D. R., Canagaratna, M. R., and Jimenez, J. L.: Hydrocarbon-like and oxygenated organic aerosols in Pittsburgh: insights into sources and processes of organic aerosols, Atmos. Chem. Phys., 5, 3289-3311, doi:10.5194/acp-5-32892005, 2005.

Zhang, Q., Jimenez, J. L., Canagaratna, M. R., Allan, J. D., Coe, H., Ulbrich, I., Alfarra, M. R., Takami, A., Middlebrook, A. M., Sun, Y. L., Dzepina, K., Dunlea, E., Docherty, K., DeCarlo, P. F., Salcedo, D., Onasch, T., Jayne, J. T., Miyoshi, T., Shimono, A., Hatakeyama, S., Takegawa, N., Kondo, Y., Schneider, J., Drewnick, F., Borrmann, S., Weimer, S., Demerjian, K., Williams, P., Bower, K., Bahreini, R., Cottrell, L., Griffin, R. J., Rautiainen, J., Sun, J. Y., Zhang, Y. M., and Worsnop, D. R.: Ubiquity and dominance of oxygenated species in organic aerosols in anthropogenically-influenced Northern Hemisphere midlatitudes, Geophys. Res. Lett., 34, L13801, doi:10.1029/2007GL029979, 2007. 